\title{
Alkene Metathesis Catalysis: A Key for Transformations of Unsaturated Plant Oils and Renewable Derivatives
}

\author{
Pierre H. Dixneuf*, Christian Bruneau and Cédric Fischmeister \\ Institut des Sciences Chimiques de Rennes, UMR 6226 CNRS-Université de Rennes, "Organometallics: Materials and Catalysis", \\ Centre for Catalysis and Green Chemistry, Campus de Beaulieu, 35042 Rennes - France \\ e-mail: pierre.dixneuf@univ-rennes1.fr \\ * Corresponding author
}

Dedicated to the memory of Yves Chauvin,

a great and inspiring pioneer in organometallic catalysis

\begin{abstract}
This account presents the importance of ruthenium-catalysed alkene cross-metathesis for the catalytic transformations of biomass derivatives into useful intermediates, especially those developed by the authors in the Rennes (France) catalysis team in cooperation with chemical industry. The cross-metathesis of a variety of functional alkenes arising from plant oils, with acrylonitrile and fumaronitrile and followed by catalytic tandem hydrogenation, will be shown to afford linear amino acid derivatives, the precursors of polyamides. The exploration of crossmetathesis of bio-sourced unsaturated nitriles with acrylate with further catalytic hydrogenation has led to offer an excellent route to $\alpha, \omega$-amino acid derivatives. That of fatty aldehydes has led to bifunctional long chain aldehydes and saturated diols. Two ways of access to functional dienes by ruthenium-catalyzed ene-yne cross-metathesis of plant oil alkene derivatives with alkynes and by cross-metathesis of bio-sourced alkenes with allylic chloride followed by catalytic dehydrohalogenation, are reported. Ricinoleate derivatives offer a direct access to chiral dihydropyrans and tetrahydropyrans via ring closing metathesis. Cross-metathesis giving value to terpenes and eugenol for the straightforward synthesis of artificial terpenes and functional eugenol derivatives without $C=C$ bond isomerization are described.
\end{abstract}

Résumé - Catalyse de métathèse d'oléfines : une clé pour des transformations d'huiles végétales insaturées et de substances renouvelables - Cet article présente l'importance de la réaction de métathèse croisée des oléfines par catalyse au ruthénium pour la transformation de dérivés de la biomasse en produits utiles pour l'industrie. Il constitue une revue des principaux travaux réalisés dans ce domaine par les auteurs dans leur équipe de catalyse à Rennes (France) en coopération avec l'industrie chimique. La métathèse croisée d'une variété d'oléfines fonctionnelles issues des huiles végétales avec l'acrylonitrile et le fumaronitrile, suivie d'une hydrogénation tandem conduit à des dérivés d'amino acides linéaires, précurseurs de polyamides par polycondensation. L'exploration de la métathèse croisée de nitriles insaturés bio-sourcés avec des acrylates a conduit à des dérivés d' $\alpha, \omega$-amino acides, tandis que les aldéhydes gras ont permis un accès rapide à des aldéhydes bifonctionnalisés à longue chaîne et à des diols saturés.

Deux voies d'accès à des diènes conjugués fonctionnels impliquant des réactions de métathèse catalysées par le ruthénium à partir d'oléfines issues de la biomasse sont décrites : l'une par métathèse croisée avec un alcyne, l'autre par métathèse croisée avec un chlorure allylique suivie 
d'une réaction de déhydrohalogénation catalytique. Les dérivés de l'acide ricinoléique ont permis un accès direct à des dihydropyrannes et tétrahydropyrannes chiraux par fermeture de cycle par métathèse. Des métathèses croisées pour valoriser des dérivés de terpènes et de l'eugénol en offrant des méthodes directes de synthèse de terpènes non naturels et de dérivés d'eugénol fonctionnels sans migration de double liaisons sont aussi présentées.

\section{INTRODUCTION}

The production of chemical industry intermediates from renewable resources is a topic of current interest to offer alternatives to petrochemicals, energy savings, and to contribute to sustainable development [1-10]. Within this trend, the use of renewable unsaturated vegetable oils is attractive [1-4]. Catalytic olefin metathesis has a strong potential for selective biomass transformations. Vegetable oils by transesterification easily release unsaturated fatty esters which offer, via cross-metathesis with alkenes, selective access to terminal alkenes or bifunctional internal olefins that are crucial intermediates for industry. Thus catalytic crossmetathesis has become a key to reveal the potential of renewable plant oils or natural terpenes [11-18].

The objective of this review is to show several applications of plant oils and terpenes discovered in Rennes with ruthenium catalysts during the last 10 years such as the ethenolysis of renewable unsaturated fatty esters to produce terminal functional alkenes, their cross-metathesis with acrylonitrile in the route to produce by sequential catalyses linear amino acid derivatives that are key intermediates for polyamide production, the cross-metathesis of renewable fatty nitriles to generate linear amino esters or diamines, and selective terpene modifications. Tandem and sequential alkene metathesis/hydrogenation catalytic reactions will be presented illustrating transformations of renewable materials with atom economy and offering new contribution to green and sustainable chemistry.

\section{ETHENOLYSIS OF METHYL OLEATE IN IONIC LIQUID FOR TERMINAL ALKENE PRODUCTION}

Catalytic ethenolysis of methyl oleate $\mathbf{1}$ has the potential to produce 1-decene $\mathbf{2}$ and methyl 9-decenoate $\mathbf{3}$, that are two useful intermediates for the preparation of lubricants [19] or polyesters [20] (Scheme 1). Initial catalysts used for this ethenolysis were $\mathrm{WCl}_{6} / \mathrm{SnMe}_{4}$ [21], and the heterogeneous $\mathrm{Re}_{2} \mathrm{O}_{7} / \mathrm{Al}_{2} \mathrm{O}_{3} / \mathrm{SnMe}_{4}[22,23]$ catalysts, as well as the first well-defined ruthenium catalysts such as I, II, IV (Fig. 1) [24-27]. These studies revealed that double bond isomerization easily takes place, is favoured by high temperature, and produces many products. However, the formation of homometathesis products 9-octadecene $\mathbf{4}$ and symmetrical diester $\mathbf{5}$ remained low.

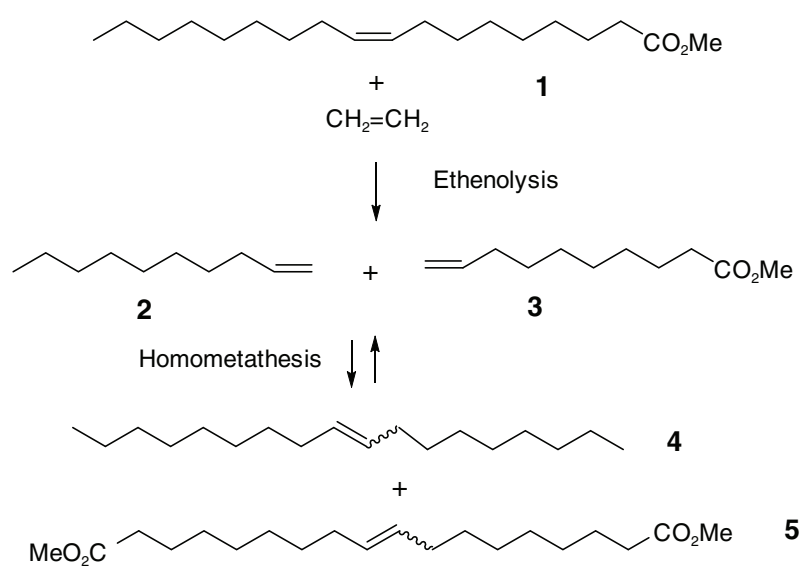

Scheme 1

Ethenolysis of methyl oleate $\mathbf{1 .}$
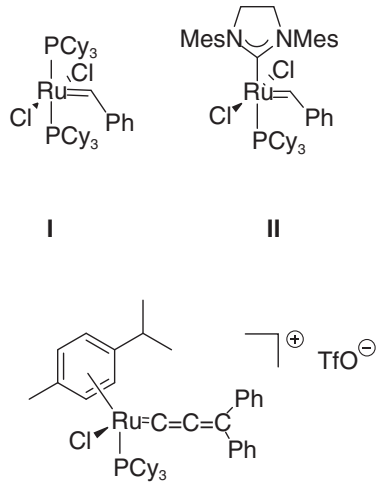

V

Figure 1

Ruthenium catalysts for alkene metathesis.

Ionic Liquids (IL) as solvents have shown their ability to favour several catalytic processes [28-32] and alkene metathesis can be performed in Room Temperature Ionic Liquids (RTIL) since 1995 [33-41]. We have shown the efficient ethenolysis of methyl oleate $\mathbf{1}$ under mild conditions with several ruthenium alkylidene catalysts in organic solvents and, for the first time, in imidazolium-type ionic 

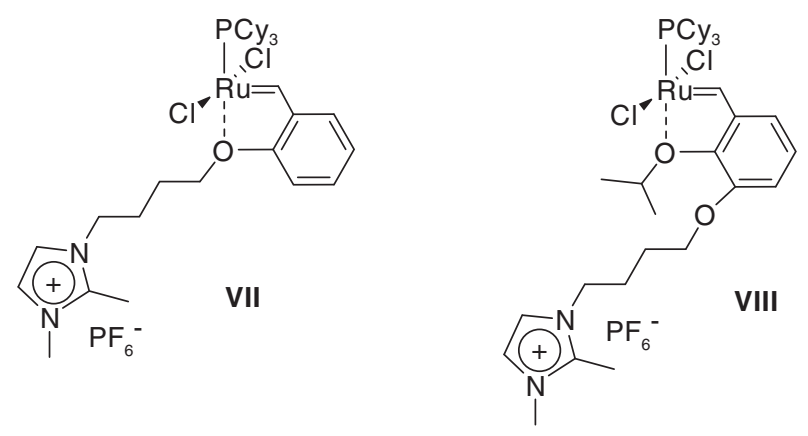

Figure 2

Ionic alkylidene-ruthenium catalysts.

liquids at room temperature without $\mathrm{C}=\mathrm{C}$ bond isomerization [42].

The ethenolysis of methyl oleate was investigated with several ruthenium catalysts I, III, IV, and $\mathbf{V}$, and the in situ prepared catalyst VI [43, 44] (Fig. 1) at $70^{\circ} \mathrm{C}$ in toluene under 1 bar of ethylene [42] (Scheme 1). These experiments demonstrated the superiority of catalyst III, which showed a better efficiency and selectivity. The best results were obtained under the mildest conditions at $20^{\circ} \mathrm{C}$ and under 1 bar pressure of ethylene leading to $93 \%$ conversion in $3.5 \mathrm{~h}$, with a total selectivity to produce 1-decene and methyl 9-decenoate in 93\% yield. The effect of the ethylene pressure is less pronounced but a higher pressure appears to improve the conversion of the reaction. The Hoveyda catalyst IV was found to allow an excellent selectivity at $20^{\circ} \mathrm{C}$ and at 1 bar but with lower conversion ( $80 \%$ instead of 93 for III).

Catalyst I was further evaluated in the ethenolysis of methyl oleate at $20^{\circ} \mathrm{C}$ and 10 bar of ethylene but in IL. Low conversion took place in $[\mathrm{bmim}][\mathrm{OTf}]([\mathrm{bmim}]=1$-butyl3-methylimidazolium), but in $[\mathrm{bmim}]\left[\mathrm{NTf}_{2}\right]$ and in [bdmim] $\left[\mathrm{NTf}_{2}\right.$ ], [bdmim] = 1-butyl-2,3-dimethylimidazolium], $79 \%$ and $83 \%$ conversion were respectively obtained after only 2 hours with excellent selectivity [42].

Two Hoveyda-type catalysts VII and VIII [41], bearing an ionic tag (Fig. 2), were evaluated in the ethenolysis of methyl oleate in the ionic liquid [bdmim] $\left[\mathrm{NTf}_{2}\right]$ at $20^{\circ} \mathrm{C}$ and 10 bar of ethylene for $2 \mathrm{~h}$. Catalyst VIII only displayed suitable catalytic activity leading to $89 \%$ conversion with high selectivity. However it was not possible to recycle this catalyst [42].

By contrast the neutral catalysts I, III, and IV (Fig. 1) in ionic liquid [bdmim] $\left[\mathrm{NTf}_{2}\right]$ at $20^{\circ} \mathrm{C}$ and 10 bar of ethylene for $2 \mathrm{~h}$ were preferable and thus subjected to consecutive runs after product extraction in hexane. We showed that catalysts I and III led to good conversion for the first run but more importantly that catalyst III could be recycled 3 times

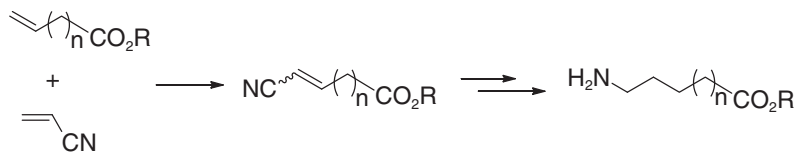

Scheme 2

From cross metathesis of fatty ester with acrylonitrile to linear aminoester.

without loss of activity and with an excellent selectivity (conversion: $1^{\text {st }}$ run $95 \%, 2^{\text {nd }}$ run $95 \%, 3^{\text {rd }}$ run $85 \%$ ) [42]. This demonstrates that it is not necessary to introduce an ionic tag in the catalyst to get excellent activity, selectivity and recyclability and that catalyst III in [bdmim] [ $\left.\mathrm{NTf}_{2}\right]$ can offer these targets for ethenolysis of methyl oleate.

\section{CROSS-METATHESIS OF ACRYLONITRILE WITH UNSATURATED ACIDS OR ESTERS: A KEY STEP TOWARD LINEAR AMINO ACID DERIVATIVES}

The transformation of unsaturated acids and esters arising from plant oils into linear amino acid intermediates constitutes a challenge to generate useful polyamides from renewables. Cross-metathesis of acrylonitrile and unsaturated acids or esters, associated with the further hydrogenation of both the $\mathrm{C}=\mathrm{C}$ and $\mathrm{CN}$ bonds, constitutes a potential strategic way for the production of polyamides [14, 15] (Scheme 2).

The first example of cross-metathesis of terminal olefins with acrylonitrile was described with the Schrock catalyst $\mathrm{Mo}\left(=\mathrm{CHCMe}_{2} \mathrm{Ph}\right)(\mathrm{NAr})\left(\mathrm{OCMe}\left(\mathrm{CF}_{3}\right)_{2}\right)$, $\mathrm{Ar}=$ 2,6-diisopropylphenyl, affording moderate yields [45]. Then ruthenium catalysts, especially containing a heterocyclic carbene ligand, improved the cross-metathesis of acrylonitrile with terminal alkenes [46-50], with an example of internal alkene in the presence of copper salt [51].

\subsection{Cross-Metathesis of Unsaturated Esters with Acrylonitrile}

We have first attempted the cross-metathesis with ruthenium catalysts of acrylonitrile with two unsaturated acids and their esters arising from renewable resources: the C11 ester 6 obtained from castor oil and its related carboxylic acid 7, and the C18 diester 8 and diacid 9 obtained via biotransformation or self-metathesis of oleic acid [52] (Scheme 3).

The cross-metathesis of the unsaturated monoester 6 with 2 equivalents of acrylonitrile was performed with the 


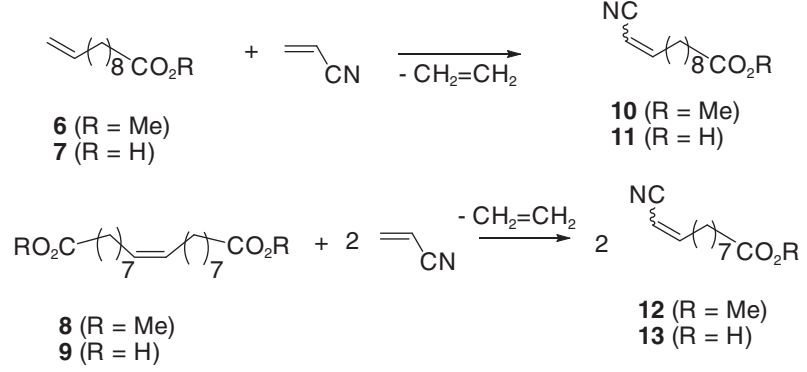

Scheme 3

Cross metathesis of fatty derivatives 6-9 with acrylonitrile.

Grubbs II and Hoveyda IV catalysts in toluene at $100^{\circ} \mathrm{C}$ (Scheme 3). The Hoveyda catalyst IV was the most efficient. With low catalyst loading $(1 \mathrm{~mol} \%)$ it allowed better conversion (95\% after $1 \mathrm{~h}$ ) giving the $\mathrm{C} 12$ nitrile ester $\mathbf{1 0}$ as a mixture of $Z$ (major) and $E$ isomers (3/1). Increasing the reagent concentration resulted in lower conversion (best concentration of $6=0.05 \mathrm{M}$ ) [52] (Scheme 3).

The similar cross-metathesis reaction was performed with acid 7. Catalyst IV ( $1 \mathrm{~mol} \%$, toluene) showed the best performance giving $90 \%$ conversion in $1 \mathrm{~h}$ at $100^{\circ} \mathrm{C}$, the $Z$ isomer being the major one $(Z / E=3.2 / 1)$ of nitrile acid 11 [52]. These experiments show that cross-metathesis is not significantly affected by the presence of an acidic functionality when catalyst IV is used.

However, it was observed that the catalyst IV progressively decomposed. Thus step by step addition of the catalyst allowed to reach better conversions and this effect was improved by dropwise addition. Lower catalyst loadings were then attempted at $100^{\circ} \mathrm{C}$ using a syringe pump equipment (dropwise addition) which offered a real breakthrough. Thus it was possible to decrease the catalyst IV loading down to $0.05 \mathrm{~mol} \%$ still leading to a high conversion (96\%) and to a TON of 1900 . The TON could be slightly increased to 2280 using a lower catalyst loading but the conversion dropped to $55 \%$ [53].

A large excess of acrylonitrile was observed to inhibit the transformation. Simultaneous slow addition of catalyst and acrylonitrile still improved the process. It was shown that addition with two syringes, one containing a mixture of ester 6 and 1 equivalent of acrylonitrile and the other one a solution of catalyst IV ( $0.025 \mathrm{~mol} \%)$ and the second equivalent of acrylonitrile, improved the process, which furnished $75 \%$ conversion of 6 and led to the highest TON (3 120) to produce the nitrile ester $\mathbf{1 0}$ [53].

Whereas the internal double bond required a higher catalyst loading of $5 \mathrm{~mol} \%$ [52], the octadec-9-enedioic

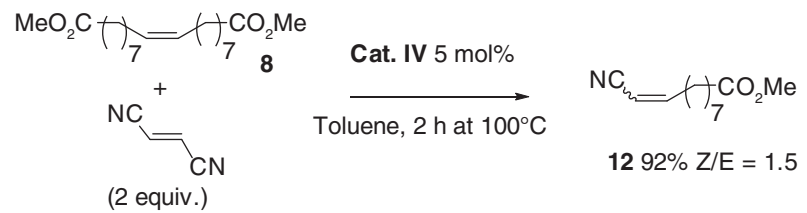

Scheme 4

Cross metathesis of diester $\mathbf{8}$ with fumaronitrile.

diester $\mathbf{8}$, derived from bioconversion of sunflower oil in the presence of Candida tropicalis M 25 [54] or by self-metathesis of oleic acid derivatives [55-57], was evaluated for cross-metathesis with acrylonitrile. Diester 8 and acrylonitrile in the presence of catalysts II and IV lead to the C11 nitrile-ester 12 (Scheme 3). Catalyst IV was also the most efficient for the reaction of $8([8]=0.1 \mathrm{M})$ with 4 equivalents of acrylonitrile in toluene at $100^{\circ} \mathrm{C}$ for $1 \mathrm{~h}$. With $5 \mathrm{~mol} \%$ of catalyst the nitrile ester 12 was obtained (86\%) as a mixture of $Z$ (major) and $E$ isomers (2.9/1) with a small amount of $\mathrm{C} 10$ ester with a terminal double bond [52]. Thus the cross-metathesis with acrylonitrile of alkenes containing an internal double bond can be efficiently achieved, as it was also possible with acrylic esters $[16,17]$. Using syringe pump addition of catalyst IV at $100^{\circ} \mathrm{C}$ for $5 \mathrm{~h}$, the unsaturated nitrile ester $\mathbf{1 0}$ was obtained in $88 \%$ yield, with high TON of 1960 [53].

The direct cross-metathesis of the diacid 9 with acrylonitrile was performed using $5 \mathrm{~mol} \%$ of catalyst IV in toluene at $100^{\circ} \mathrm{C}$ for $1 \mathrm{~h}$ to give $90 \%$ conversion of 9 and the formation of the diacid $13(Z / E=2.4)$ (Scheme 3$)$.

\subsection{Cross-Metathesis of Diester 8 with Fumaronitrile}

The cross-metathesis of fumaronitrile ( 2 equivalents) instead of acrylonitrile with the diester 8 (Scheme 4) can be performed using ruthenium catalyst IV $(5 \mathrm{~mol} \%)$ and the nitrile ester 12 was obtained in 92\% isolated yield [52]. These experiments show that fumaronitrile can be used for crossmetathesis, although it is more profitable to use the cheapest and readily available acrylonitrile.

\subsection{Cross-Metathesis of Methyl Oleate with Acrylonitrile and Fumaronitrile}

Analogously, methyl oleate $\mathbf{1}$ with an internal double bond, was reacted with an excess of acrylonitrile in toluene at $100^{\circ} \mathrm{C}$ for $2 \mathrm{~h}$ with $5 \mathrm{~mol} \%$ of ruthenium catalyst $\mathrm{IV}$ and led to full conversion of methyl oleate and to a mixture of the expected nitrile ester 12 and unsaturated nitrile $\mathbf{1 5}$ in 


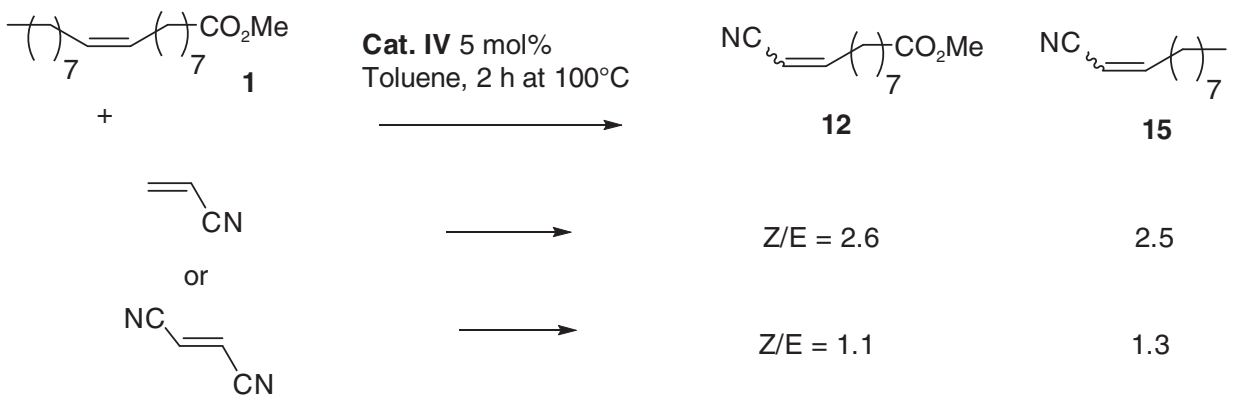

Scheme 5

Cross metathesis of methyl oleate with acrylonitrile and fumaronitrile.

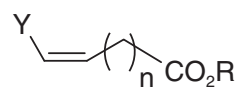

6 and 8
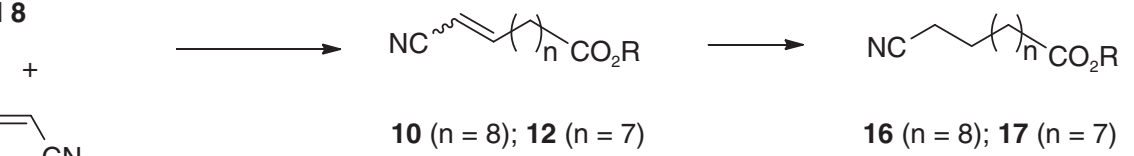

6: $\mathrm{Y}=\mathrm{H} ; \mathrm{n}=8$

8: $\mathrm{Y}=\left(\mathrm{CH}_{2}\right)_{7} \mathrm{CO}_{2} \mathrm{Me} ; \mathrm{n}=7$

Scheme 6

Tandem catalytic cross metathesis of fatty esters with acrylonitrile and hydrogenation.

equal amounts [52] (Scheme 5). Cross-metathesis of methyl oleate with fumaronitrile in the presence of $5 \mathrm{~mol} \%$ of catalyst $\mathbf{I V}$ in toluene at $100^{\circ} \mathrm{C}$ for $2 \mathrm{~h}$ also provided $\mathbf{1 2}$ and $\mathbf{1 5}$ as a mixture of $E$ and $Z$ isomers, in equal proportions [52] (Scheme 5).

\section{HYDROGENATION OF NITRILE ESTERS 10 AND 12 INTO NITRILE ESTERS 16 AND 17}

The possibility of synthesizing saturated nitrile-esters from renewable oils by tandem cross-metathesis/hydrogenation catalysis was investigated. After cross-metathesis of ester 6 and diester $\mathbf{8}$ with catalyst $\mathbf{I V}$, and formation of the nitrileesters 10 and 12, the crude reaction mixture containing residual ruthenium catalyst was concentrated, transferred to an autoclave, and hydrogenated without additional catalyst under 10 bar of $\mathrm{H}_{2}$ to quantitatively give the single compounds 16 and 17, respectively (Scheme 6) [52]. This set of reactions constitutes an example of sequential alkene metathesis/hydrogenation catalytic reactions. However the hydrogenation catalyst is not powerful enough yet to reduce the nitrile group into terminal amine.

\section{TANDEM ALKENE METATHESIS / HYDROGENATION CATALYSES: FROM PLANT OIL UNSATURATED ESTERS TO LINEAR AMINO ESTERS}

The hydrogenation of aliphatic nitriles into primary amines requires more efficient catalysts operating in more drastic conditions. Takemoto et al. [58] and Li et al. [59] reported examples of homogeneous hydrogenation of nitriles into primary amines when alkoxide were added to ruthenium catalyst. Das et al. [60] and Enthaler et al. [61, 62] also showed that addition of ${ }^{t} \mathrm{BuOK}$ and phosphine to simple ruthenium complex led to the fast hydrogenation of various nitriles and by replacing the phosphine ligand by a $N$-heterocyclic carbene, milder conditions could be operating [63].

We have now shown that, after performance of the ruthenium alkylidene-catalyzed cross-metathesis of alkenes with acrylonitrile, when the catalytic hydrogenation of the resulting nitrile ester with the residual ruthenium catalyst was carried out in the presence of ${ }^{t} \mathrm{BuOK}$ or even $\mathrm{KOH}$, the hydrogenation of the nitrile group into primary amine could be obtained, without formation of secondary amine, and that the $\alpha, \omega$-linear amino ester, a precursor of polyamides, could be obtained in excellent yield [64, 65] (Scheme 7). 


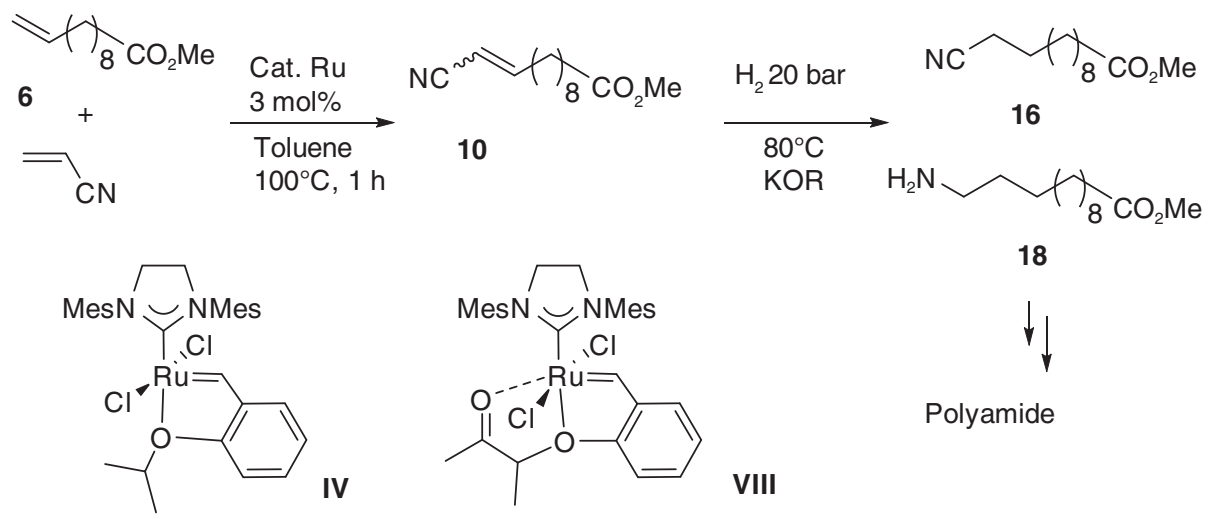

Scheme 7

Tandem catalysis cross metathesis/hydrogenation of ester $\mathbf{6}$.
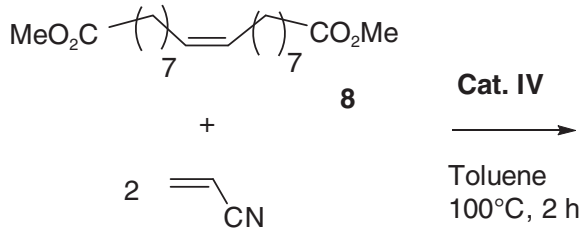<smiles>N#CC=CCCC(=O)O</smiles>

12

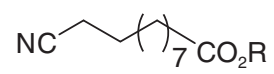

17

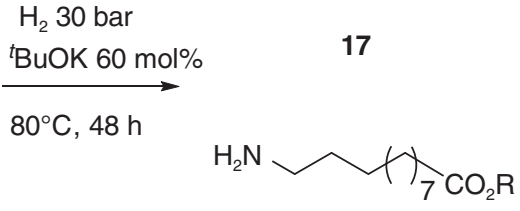

19

Scheme 8

Sequential catalytic synthesis of aminoester $\mathbf{1 9}$ from diester $\mathbf{8}$.

Thus, after the cross-metathesis of methyl oleate with acrylonitrile in the presence of the best catalyst: the Hoveyda catalyst IV $(3 \mathrm{~mol} \%)$ at $100^{\circ} \mathrm{C}$ for $1 \mathrm{~h}$ in toluene, the reaction mixture containing the residual ruthenium was transferred into an autoclave. Addition of $30 \mathrm{~mol} \%$ of ${ }^{t} \mathrm{BuOK}$ under 20 bar of hydrogen for $44 \mathrm{~h}$ led to the formation of $92 \%$ of methyl 12-aminododecanoate $\mathbf{1 8}$. No remaining nitrile ester 16 was observed [64]. It is noteworthy that this reaction takes place without formation of secondary amine as observed in many hydrogenation of nitriles into amines.

The evaluation of other basic additives such as potassium hydroxide, sodium hydroxide, or cesium carbonate showed that $\mathrm{KOH}$ could be efficiently used but in $60 \mathrm{~mol} \%$. Using only $30 \mathrm{~mol} \%$ of KOH led to $56 \%$ yield of $\mathbf{1 8}$ together with $40 \%$ yield of nitrile ester 16 [64] (Scheme 7).

We also evaluated the influence of the initial ruthenium alkylidene catalyst and we showed that the Umicore M51 catalyst VIII provided similar results as catalyst IV but with the advantage of requiring only $15 \mathrm{~mol} \%$ of ${ }^{t} \mathrm{BuOK}$ [64] (Scheme 7).

We explored the sequential cross-metathesis with acrylonitrile and hydrogenation of the renewable fatty diester $\mathbf{8}$
[64] (Scheme 8). The reaction of 8 with 4 equivalents of acrylonitrile with $6 \mathrm{~mol} \%$ of catalyst IV was first performed in toluene for $2 \mathrm{~h}$ at $100^{\circ} \mathrm{C}$ and then the reaction mixture was transferred into an autoclave charged with $60 \mathrm{~mol} \%$ of ${ }^{t} \mathrm{BuOK}, 30$ bar of $\mathrm{H}_{2}$. After $48 \mathrm{~h}$ at $80^{\circ} \mathrm{C}$, the $\mathrm{C} 11$ aminoester 19 was isolated in $78 \%$ yield.

\section{SELECTIVE HYDROGENATION OF NITRILE ESTERS WITH RUTHENIUM ALKYLIDENE CATALYSTS}

A tandem metathesis/hydrogenation process in the presence of ruthenium alkylidene catalyst has already been used to prepare saturated polymers [66-68]. Thus, we have explored whether ruthenium-benzylidene and ruthenium-indenylidene olefin metathesis catalysts could also perform hydrogenation of fatty alkyl nitriles and could be more efficient than the residual ruthenium arising from cross-metathesis.

The hydrogenation of methyl 11-cyano undec-10-enoate 10 (Scheme 9), was first performed in the presence of catalyst IV (3 mol\%) and $30 \mathrm{~mol} \%$ of ${ }^{t} \mathrm{BuOK}$, under hydrogen pressure of 20 bar at $80^{\circ} \mathrm{C}$ for $39 \mathrm{~h}$. It quantitatively 

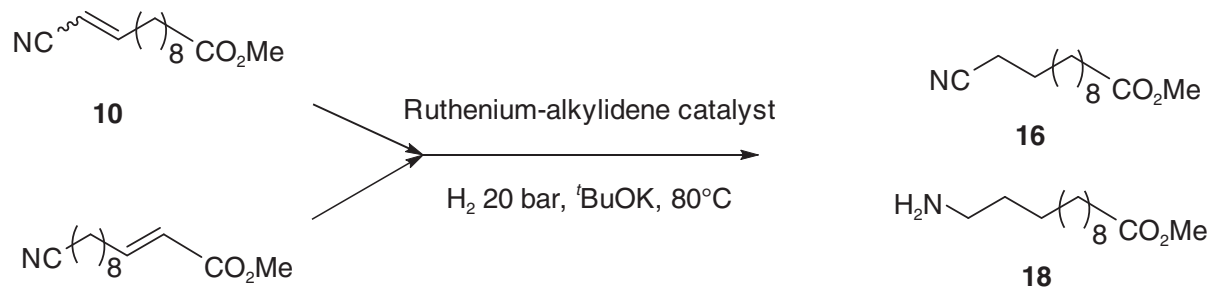

20

Scheme 9

Catalytic hydrogenation of nitrile esters into linear amino ester $\mathbf{1 8 .}$
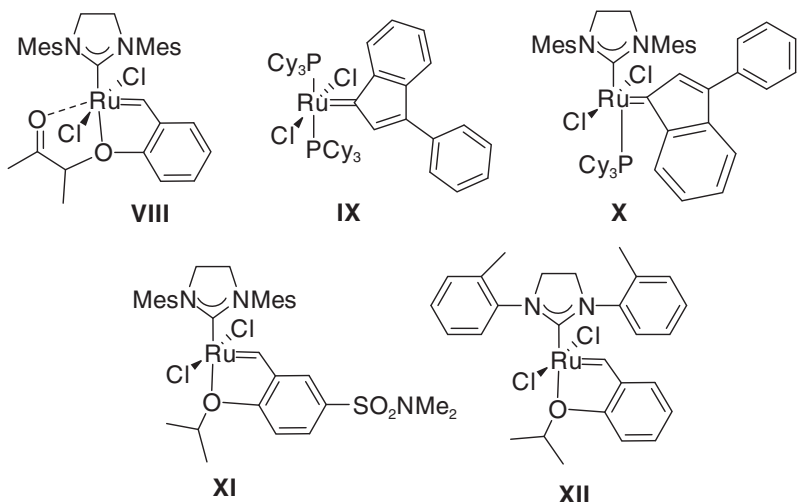

Figure 3

Alkylidene-ruthenium catalysts for alkene metathesis and hydrogenation.

provided the saturated $\mathrm{C} 12 \alpha, \omega$-amino ester 18, which was isolated in 89\% yield [69] (Scheme 9). The presence of ${ }^{t} \mathrm{BuOK}$ not only created the hydrogenation catalyst but was shown to inhibit the formation of secondary amines.

The catalyst activity of ruthenium-alkylidenes I, II, and VIII-X (Fig. 3) was evaluated on the hydrogenation of 10, in the presence of $30 \mathrm{~mol} \%$ of ${ }^{t} \mathrm{BuOK}$. The best results were obtained with catalyst $\mathbf{X}$ and II requiring the presence of only $15 \mathrm{~mol} \%$ of ${ }^{t} \mathrm{BuOK}$ to get quantitative formation of 18 after $16 \mathrm{~h}$. More importantly these two catalysts could perform the quantitative formation of $\mathbf{1 8}$ by hydrogenation of nitrile ester $\mathbf{1 0}$ at $80^{\circ} \mathrm{C}$ for $16 \mathrm{~h}$ [69] (Scheme 9).

Another approach for the preparation of the same $\mathrm{C} 12 \alpha, \omega$-amino ester $\mathbf{1 8}$ can arise from the hydrogenation of methyl (E)-11-cyanoundec-2-enoate 20, which is arising from cross-metathesis of 10-undecenenitrile with methyl acrylate (see Sect. 6). The catalytic hydrogenation of nitrile ester 20 using $3 \mathrm{~mol} \%$ of catalyst IV under an initial hydrogen pressure of 20 bar at $80^{\circ} \mathrm{C}$ for $40 \mathrm{~h}$ in the presence of $30 \mathrm{~mol} \%$ of ${ }^{t} \mathrm{BuOK}$, led to complete conversion of compound 20 and $75 \%$ of compound $\mathbf{1 8}$ and $22 \%$ of compound
16 were obtained [69] (Scheme 9). The hydrogenation of 20 with ruthenium catalysts I, II, and VIII-X (3 $\mathrm{mol} \%)$ in the presence of $30 \mathrm{~mol} \%$ of ${ }^{t} \mathrm{BuOK}$ provided excellent yields of amino ester 18, except for catalyst $\mathbf{I}$. On lowering the catalyst loading to $1 \mathrm{~mol} \%$, and on shortening the reaction time to $16 \mathrm{~h}$, ruthenium catalysts II and $\mathbf{X}$ offered the best efficiency for the production of $\mathbf{1 8}$ from nitrile ester $\mathbf{2 0}$ [69] (Scheme 9).

\section{CROSS-METATHESIS OF RENEWABLE 10-UNDECENENITRILE AND METHYL ACRYLATE: NEW SYNTHESIS OF POLYAMIDES PRECURSORS}

In some examples it was shown that acrylonitrile inhibits the ruthenium-catalysed cross-metathesis of functional alkenes, whereas methyl acrylate does not inhibit this reaction as some cross-metathesis can be performed in bulk in methyl acrylate [16, 17, 70-72]. Thus, it appeared that the linear amino ester 18 could also arise from the cross-metathesis of the 10-undecenenitrile $\mathbf{2 1}$ with methyl acrylate followed by hydrogenation. 10-Undecenenitrile $\mathbf{2 1}$ is a bio-sourced derivative arising from ammoxidation of 10-undecenoic acid [73]. 10-Undecenoic acid is produced by thermolysis of ricinoleic acid arising from castor oil followed by hydrolysis and it has already been used for the industrial production of polyamide PA11 in the Rilsan process [74].

The cross-metathesis of 10-undecenenitrile 21 with methyl acrylate (2 equivalents) in toluene was attempted with (NHC) $\mathrm{Ru}$ alkylidenes II, IV, VIII, and XI (0.5 mol\%) (Fig. 1, 3). The catalysts IV, VIII and XI bearing a chelating benzylidene ligand were very efficient, at temperature of $50^{\circ} \mathrm{C}$ or even room temperature, to quantitatively produce nitrile ester 20, with high percentage of the $E$ isomer [75] (Scheme 10). This cross-metathesis transformation is not so easily performed than that of oleate with methyl acrylate but it occurs much more easily than the cross-metathesis of methyl oleate with acrylonitrile, thus showing the inhibition by the nitrile function especially when it is conjugated with the double bond. 
To improve the TON values, catalyst IV was slowly injected with a syringe pump apparatus. The catalyst solution was added within $2 \mathrm{~h} 40 \mathrm{~min}$ and the reaction was prolonged for further $5 \mathrm{~h}$. With a catalyst loading of $0.05 \mathrm{~mol} \%$, the temperature could be decreased down to $50^{\circ} \mathrm{C}$ to ensure a TON close to 2000 with almost complete conversion.

With lower catalyst loadings, a higher temperature of $100^{\circ} \mathrm{C}$ was required to reach good conversion. Thus with $0.01 \mathrm{~mol} \%$ of catalyst IV, $92 \%$ conversion of $\mathbf{2 1}$ was obtained and led to $92 \%$ of nitrile ester $\mathbf{2 0}$, thus providing a high TON of 9200 . The increase of the concentration of the nitrile 21 to $0.5 \mathrm{M}$ improved the conversion and catalyst IV loading could be decreased to $0.005 \mathrm{~mol} \%$. At $100^{\circ} \mathrm{C}$ a TON of 17200 could be reached.

Similarly to the transformation of oleate into linear amino ester (Scheme 7) we have investigated the tandem crossmetathesis/hydrogenation in the presence of ${ }^{t} \mathrm{BuOK}$ starting with cross-metathesis of nitrile $\mathbf{2 1}$ with methyl acrylate, followed by hydrogenation of the formed nitrile ester, taking profit of the ruthenium residue as hydrogenation catalyst. The nitrile hydrogenation could not be achieved with the very low loading of $0.05 \mathrm{~mol} \%$ of catalyst IV used for the cross-metathesis reaction. Thus the metathesis was performed during the first step, with $3 \mathrm{~mol} \%$ of catalyst loading, and hydrogenation with the corresponding residual ruthenium was performed under 20 bar of hydrogen at $100^{\circ} \mathrm{C}$ to give complete conversion into the saturated amino ester $\mathbf{1 8}$ which was obtained only in the presence of $30 \mathrm{~mol} \%$ of ${ }^{t} \mathrm{BuOK}$ with $96 \%$ yield [75] (Scheme 10).

\section{CROSS-METATHESIS OF METHYL RICINOLEATE WITH ACRYLONITRILE AND METHYL ACRYLATE}

Ricinoleic derivatives are useful renewable materials that have a hydroxy functionality which offers an extra-value for further derivatization. However, the homoallylic hydroxyl group may also prevent alkene metathesis [76-79]. We thus studied the cross-metathesis of methyl ricinoleate $\mathbf{2 2}$ with acrylonitrile using both the single dose addition and the dropwise slow addition of catalyst IV (Scheme 11). This transformation led us to the formation of nitrile ester $\mathbf{1 2}$

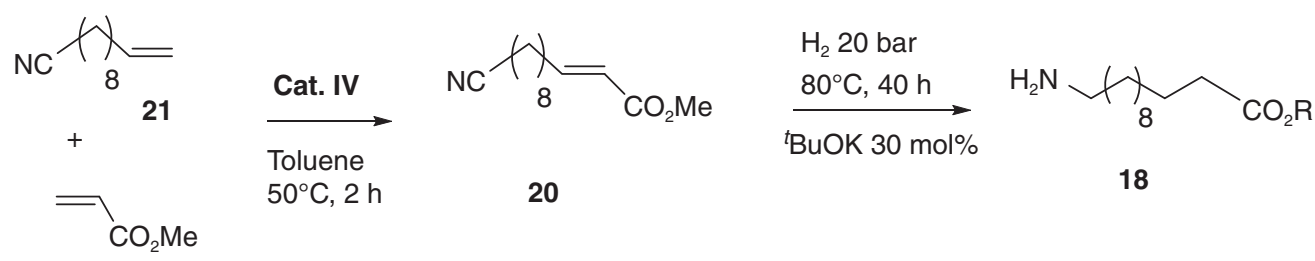

Scheme 10

Sequential catalytic synthesis of amino ester $\mathbf{1 8}$ from unsaturated nitrile $\mathbf{2 1 .}$
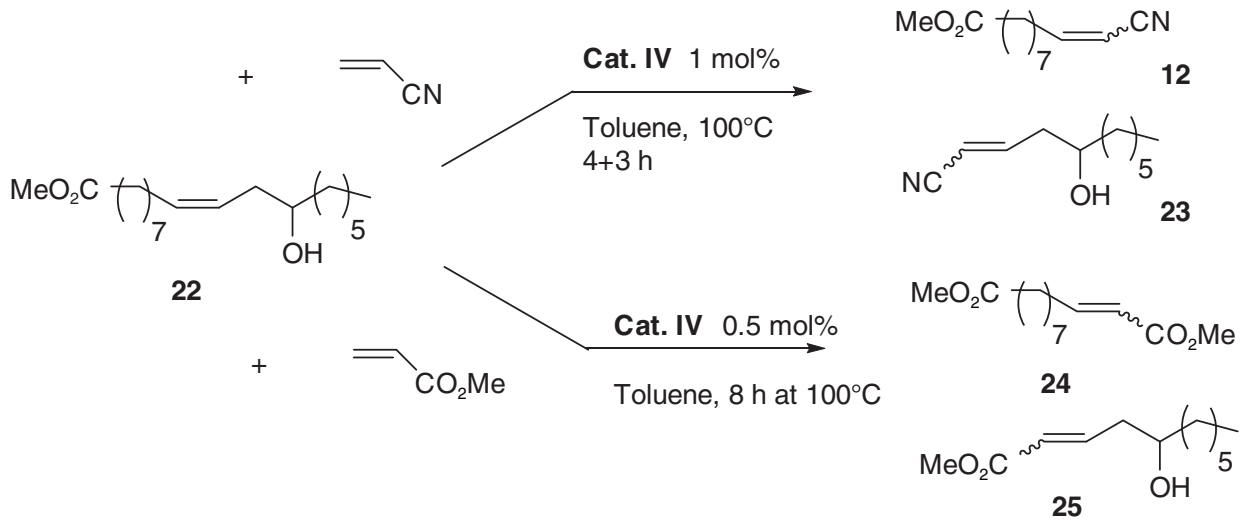

Scheme 11

Cross metathesis of methyl ricinoleate $\mathbf{2 2}$ with acrylonitrile and methyl acrylate. 
obtained also from the cross-metathesis of diester $\mathbf{8}$ with acrylonitrile, and to the new compound 23. Single dose addition of $1 \mathrm{~mol} \%$ of Hoveyda catalyst $\mathbf{I V}$ at $80^{\circ} \mathrm{C}$ allowed full conversion of 22 providing $\mathbf{1 2}$ in $82 \%$ and $\mathbf{2 3}$ in $76 \%$ isolated yields. By using the dropwise slow addition of catalyst a higher TON (920) was reached. Using $0.1 \mathrm{~mol} \%$ of catalyst 12 and 23 were obtained in $73 \%$ and $66 \%$ yields, respectively (Scheme 11). These first results demonstrate that the transformation of methyl ricinoleate is more difficult to perform than cross-metathesis of diester $\mathbf{8}$, thus illustrating the inhibition presented by the homoallylic alcohol functionality with respect to a simple internal alkene [14, 53].

An alternative route for the production of the fatty diesters was explored by the cross-metathesis of methyl ricinoleate 22 with methyl acrylate, for the production of the diester 24 (89\%) with concomitant formation of hydroxyl ester $\mathbf{2 5}$ $(85 \%)$, which is a potential precursor of the fatty diol by hydrogenation (Scheme 11). The slow addition of catalyst IV afforded $90 \%$ conversion of 22 using $0.1 \mathrm{~mol} \%$ of catalyst IV and a high TON (900) was reached [53].

\section{BIFUNCTIONAL ALDEHYDE DERIVATIVES VIA SELF- AND CROSS-METATHESIS OF UNSATURATED ALDEHYDES}

The aldehyde functionality is often reached in industry via hydroformylation of alkenes, and allows the access to a large variety of functional compounds by selective catalytic transformations. Alkene metathesis catalysis, especially promoted by well-defined homogeneous ruthenium alkylidenes and indenylidenes, is offering functionalization by double bond exchange and with the advantage of tolerating a large variety of functional groups including the formyl group. The previous successful results of cross-metathesis motivated our exploration of the cross-metathesis of unsaturated aldehydes arising from derivatives of plant oils, especially via cross-metathesis with acrylonitrile or via self-metathesis for the production of linear diol precursors or amino alcohols.
The 10-undecylenic aldehyde $\mathbf{2 6}$ is a renewable derivative obtained from thermal treatment of castor oil [76, 77]. Its self-metathesis was attempted to produce the $\mathrm{C} 20$ dialdehyde a key intermediate for the production of symmetrical diol or diamine and the formation of polyesters and polyamides. The self-metathesis of aldehyde $\mathbf{2 6}$ was attempted at $40^{\circ} \mathrm{C}$ in toluene first with catalysts II and IV, containing a $N$-heterocyclic carbene ligand. They showed high catalytic activity but also yielded isomerization by-products. The catalysts I and III containing the $\mathrm{PCy}_{3}$ ligand offered better production of dialdehyde 27 . The catalyst III afforded $79 \%$ conversion of $\mathbf{2 6}$ with only $9 \%$ of self-metathesis byproduct [80] (Scheme 12).

The direct synthesis of eicosane-1,20-diol $\mathbf{2 8}$ was then directly performed from the mono aldehyde $\mathbf{2 6}$, using tandem self-metathesis/hydrogenation catalysis. The aldehyde 26 was first transformed via self-metathesis with catalyst III or XII, and the crude products containing the ruthenium residue were transferred into an autoclave and hydrogenated under 10 bar of $\mathrm{H}_{2}$ at $50^{\circ} \mathrm{C}$ for $24 \mathrm{~h}$. The diol 28 was isolated in $70 \%$ yield. [80] (Scheme 12).

The cross-metathesis of unsaturated aldehyde $\mathbf{2 6}$ with various acrylic derivatives was attempted as a route to shorter bifunctional compounds [80] (Scheme 13). The reaction of 26 with acrolein ( 2 equivalents) with $1 \mathrm{~mol} \%$ of catalyst IV in toluene at $100^{\circ} \mathrm{C}$ led to the formation of the unsaturated dialdehyde $\mathbf{2 9}$, which was isolated in $78 \%$ yield

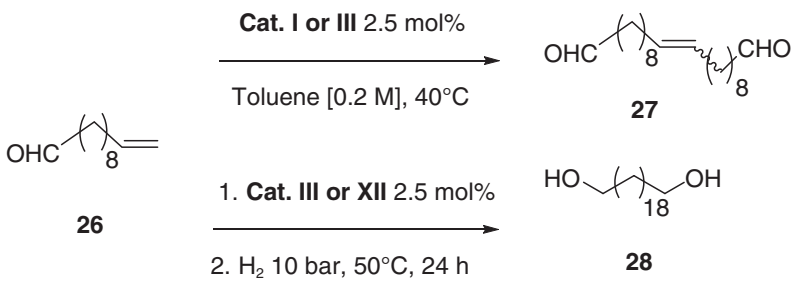

Scheme 12

Homometathesis of 10-undecylenic aldehyde $\mathbf{2 6}$ and hydrogenation of dialdehyde 27.

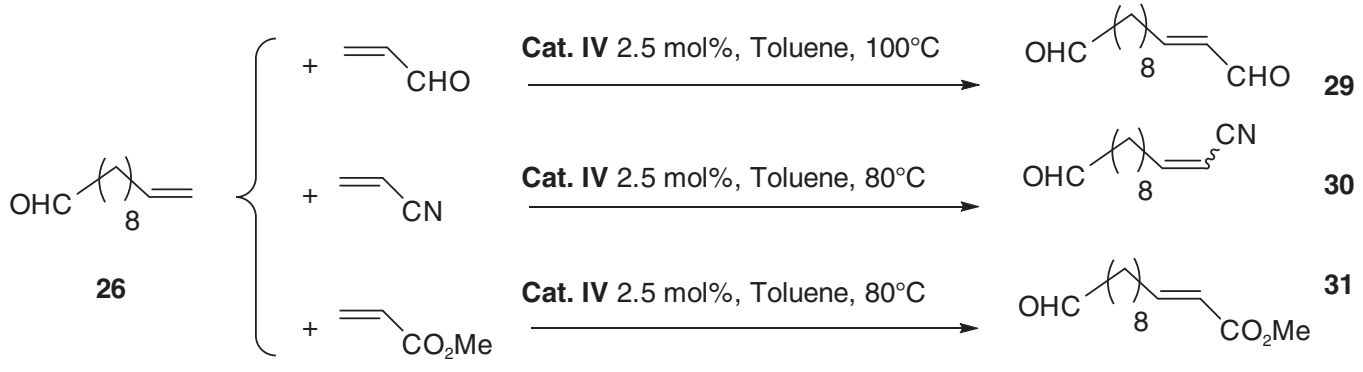

Scheme 13

Cross-metathesis of 10-undecylenic aldehyde $\mathbf{2 6}$ with acrylic derivatives. 
as a pure $E$ isomer. The corresponding $\mathrm{C} 12$ terminal diol was obtained directly from 26 using tandem cross-metathesis with acrolein and catalyst $\mathbf{I V}$, followed by hydrogenation with 10 bar of $\mathrm{H}_{2}$ at $50^{\circ} \mathrm{C}$ for $24 \mathrm{~h}$. The saturated $\mathrm{C} 12$ diol was isolated in $72 \%$ yield [80].

$\omega$-Nitrile-aldehydes have the potential to produce linear amino alcohols and amino acids as a route to polyamides and mixed polyamide-esters. The cross-metathesis of aldehyde 26 with acrylonitrile ( 2 equivalents) in the presence of catalyst IV was performed at $80^{\circ} \mathrm{C}$ in toluene for $5 \mathrm{~h}$ and led to 30 in 94\% isolated yield [80] (Scheme 13).

The cross-metathesis of $\mathbf{2 6}$ with methyl acrylate (2 equivalents) led to the isolation of the $E$ isomer of the formyl ester 31 in $92 \%$ yield. The formation of $\mathbf{3 1}$ was achieved with catalyst IV $(1 \mathrm{~mol} \%)$ in toluene at $80^{\circ} \mathrm{C}$ for $16 \mathrm{~h}$. It is noteworthy that the cross-metathesis of $\mathbf{2 6}$ with acrylic acid can be performed under similar conditions and after only $14 \mathrm{~h}$ the corresponding formyl carboxylic acid was obtained in $84 \%$ yield [80].

\section{CROSS-METATHESIS OF BIO-SOURCED FATTY NITRILES WITH ACRYLONITRILE}

In order to evaluate the influence of a nitrile group at the terminal position of a fatty acid derivative on the crossmetathesis with acrylonitrile, 10-undecenenitrile 21 was subjected to cross metathesis with acrylonitrile to produce the dinitrile 32 (Scheme 14) [81]. We found that this reaction was efficiently achieved in the presence of Hoveyda IV and Umicore M51 VIII catalysts. The best results were obtained with the dropwise addition of the catalyst to the reaction mixture and a turnover number of 12800 was reached at $80 \%$ conversion with a catalyst loading of $0.00625 \mathrm{~mol} \%$ in diethyl carbonate at $120^{\circ} \mathrm{C}$ for $5 \mathrm{~h}$.

These excellent results confirm that suitable experimental conditions make possible the selective cross-metathesis of acrylonitrile without isomerization side reactions in the presence of another nitrile functionality.

\section{METATHESIS OF 1-DECENE WITH ALKYNES: A SYNTHESIS OF FATTY DIENES}

The synthesis of conjugated dienes by ene-yne crossmetathesis [82] is another interesting pathway for the transformation of Fatty Acid Methyl Esters (FAME). In 2009, we reported the first example of such transformation applied to methyl oleate $\mathbf{1}$ and to the diester 8 [83]. However, our initial attempts to apply this transformation directly to methyl oleate failed whatever the cross-partner, i.e. terminal or internal alkyne. This result was likely due to the lower reactivity of vinylcarbene catalyst species generated in this reaction. To overcome this issue, we set up a sequential reaction involving an initial ethenolysis of methyl oleate followed by ene-yne cross-metathesis of the resulting terminal alkynes (Scheme 15).

This sequential reaction was performed in a one-pot fashion employing the Hoveyda first generation catalyst III for the initial ethenolysis step and the second generation Grubbs catalyst II for the ene-yne cross-metathesis step (Scheme 15). The choice of a first generation catalyst for the ethenolysis step was dictated by previous results demonstrating the better performances of this catalyst in ethenolysis of methyl oleate in particular since no $\mathrm{C}=\mathrm{C}$ double-bond migration and low amounts

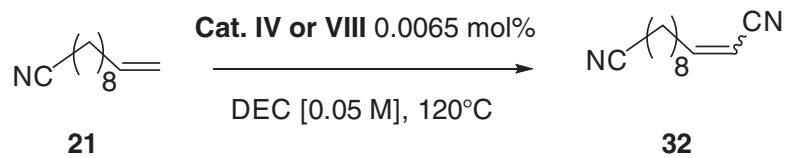

Scheme 14

Cross-metathesis of 10-undecenenitrile 21 with acrylonitrile.
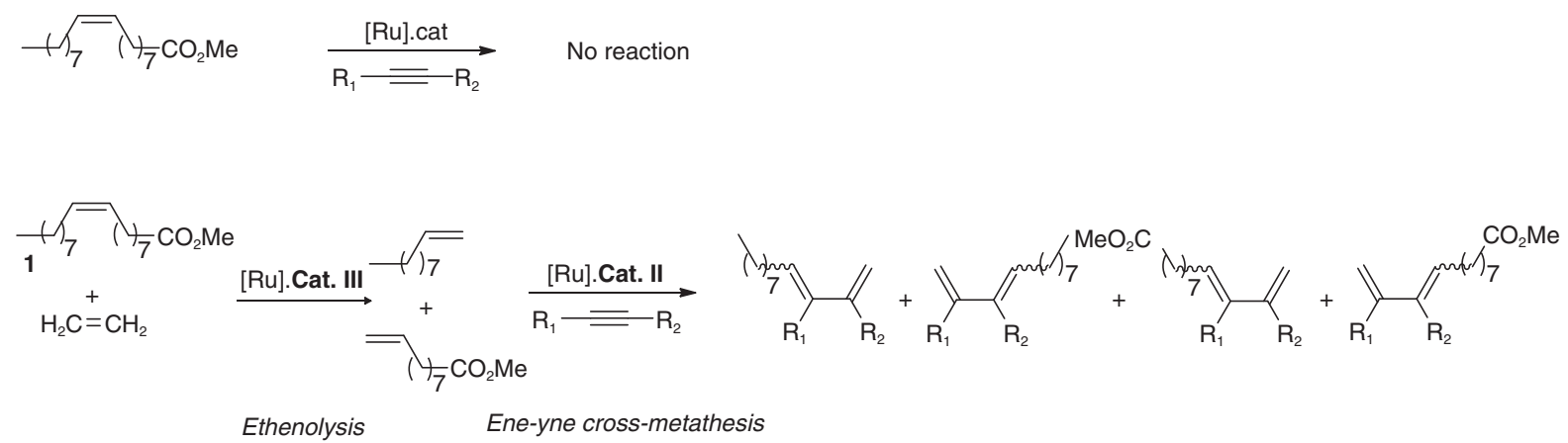

Scheme 15

Sequential ethenolysis and ene-yne cross-metathesis of methyl oleate. 

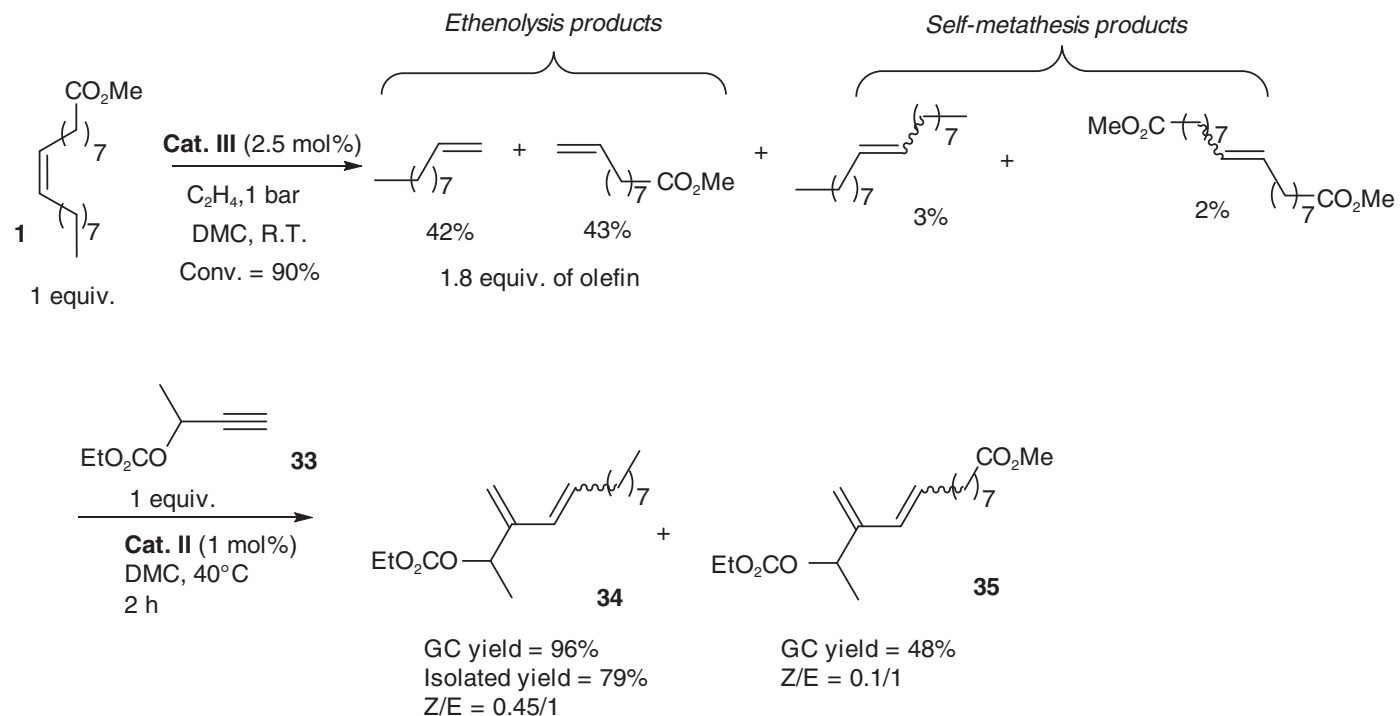

Scheme 16

One-pot ethenolysis/ene-yne cross-metathesis of methyl oleate with propargyl carbonate.<smiles>COC(C)=CC=CC(C)=O</smiles>

1 equiv.

8

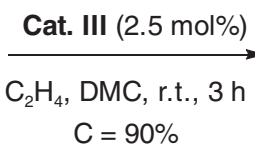

$\mathrm{C}=90 \%$

$C=90 \%$

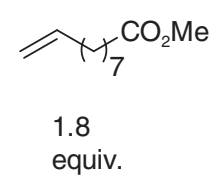

equiv.
Cat. II (1 mol\%)

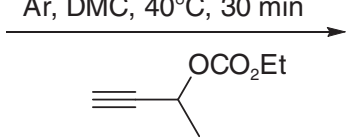

0.9 equiv.

$+$

0.9 equiv.<smiles>C=C(C=CC(C)=O)C(C)OC(C)=O</smiles>

GC yield $96 \%$ $\mathrm{Z} / \mathrm{E}=0.14 / 1$

GC yield $90 \%$ with an alkene/alkyne ratio $=2$

Scheme 17

One-pot ethenolysis/ene-yne cross-metathesis using continuous alkyne addition.

of self-metathesis products were observed with this catalyst $[41,42]$. As depicted in Scheme 16, the initial ethenolysis of methyl oleate proceeded with high conversion furnishing the desired ethenolysis product and very low amounts of selfmetathesis products. Addition of 1 equivalent of propargyl carbonate 33 and $1 \mathrm{~mol} \%$ catalyst II produced the expected dienes $\mathbf{3 4 ,} 35$ in high yields as a mixture of stereoisomers. It must be underlined that these reactions were conducted in dimethyl carbonate, a solvent earlier found to be fully compatible with olefin metatheses transformations including ethenolysis [84].

Similarly to cross-metatheses of olefins, ene-yne crossmetathesis requires an excess of one reagent (usually 2 equivalents of olefinic partner) to proceed efficiently. This constitutes a major impediment regarding sustainability in particular for the transformation of a bio-sourced compound. This issue was overcome by the implementation of a slow addition of the alkyne reagent in order to maintain an excess of olefin all along the transformation [85]. As shown in Scheme 17 the diester 8 was first submitted to ethenolysis delivering 1.8 equivalent of methyl decenoate. The catalyst II and 0.9 equivalent of alkyne were then added and the ene-yne cross-metathesis reaction started. The second 0.9 equivalent of alkyne was then slowly added using a syringe pump apparatus. This reaction led to a higher yield in diene $\mathbf{3 5}$ than the previous protocol employing an excess of olefin hence improving the sustainability of this reaction sequence.

Conjugated dienes are valuable building blocks in a number of organic transformations. In particular, dienes arising 

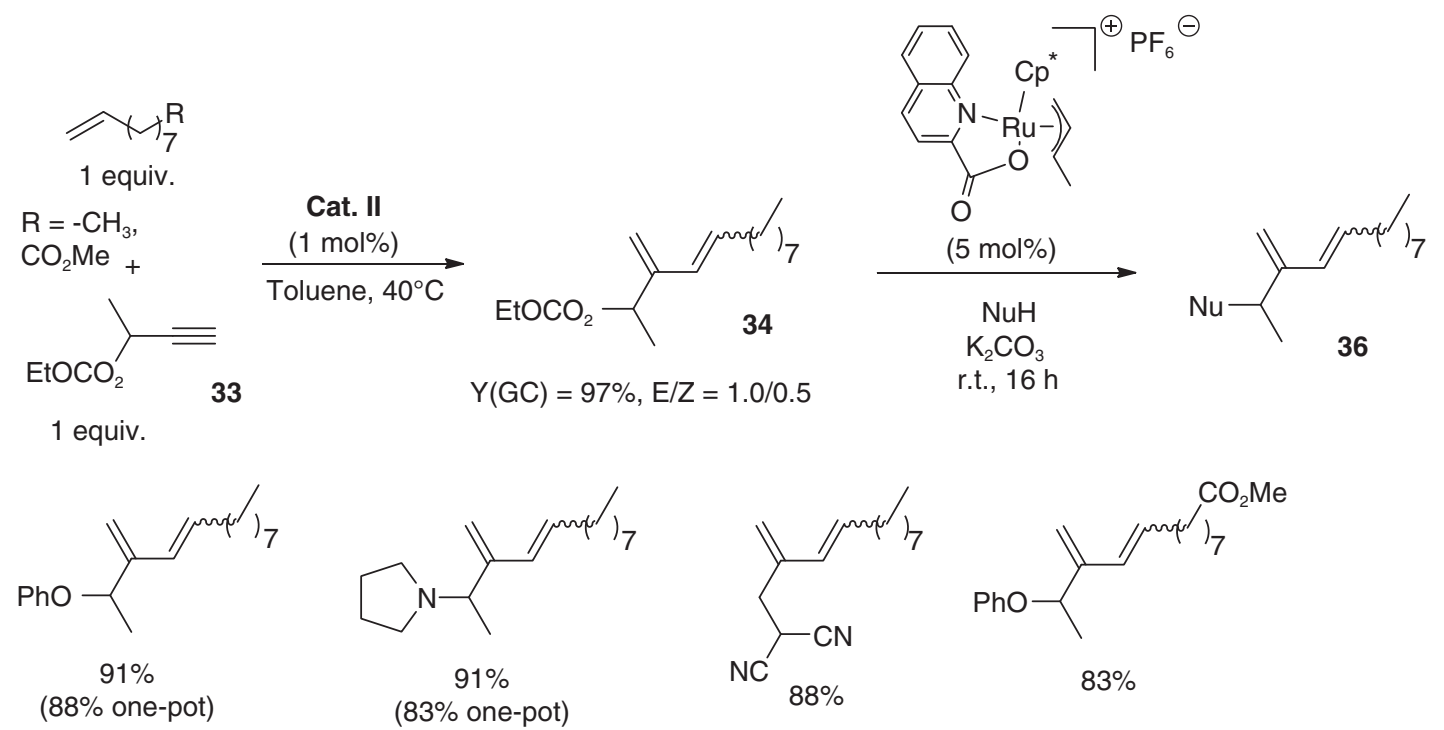

Scheme 18

Sequential ene-yne metathesis and allylic substitution from conjutated dienes.

from ene-yne metathesis have received attention in Diels-Alder transformations [86]. To extend the scope of the transformations of these conjugated dienes, we turned our attention to the nucleophilic allylic substitution reaction. The choice of the alkyne involved in the initial ene-yne crossmetathesis is crucial to allow for further allylic activation. Hence, $n$-decene and methyl decenoate were reacted with the propargylic carbonate $\mathbf{3 3}$ to furnish the corresponding dienes in high yields [87]. These dienes were then transformed by nucleophilic allylic substitution catalyzed by a ruthenium complex previously disclosed in our group [88]. The corresponding products $\mathbf{3 6}$ were obtained in high yields and regioselectivity. Of note, this transformation could be performed in high yields in a one-pot manner without isolation of the diene intermediate (Scheme 18).

\section{FINE CHEMICAL FROM FATTY ACID METHYL ESTERS (FAME)}

As exemplified in this article the transformation of FAME is almost exclusively dedicated to the synthesis of polymer precursors. Only rare examples deal with the transformation of FAME into fine chemicals [89]. In 2012, we reported the transformation of methyl ricinoleate into a variety of pyran and lactone derivatives of interest as fragrance ingredients. The synthesis strategy required a preliminary transformation of the hydroxyl functional group of methyl ricinoleate $\mathbf{3 7}$ with various olefinic reagents followed by Ring Closing Metathesis (RCM) of the resulting dienes [90]. Hence, following a Ruthenium-Catalyzed (RC) allylation of methyl ricinoleate, RCM delivered a variety of dihydropyrans 38-40 along with methyl 9-decenoate or its self-metathesis diester as co-products of the reaction (Scheme 19). The ratio of these two valuable polymer precursors could be easily tuned by a judicious selection of the RCM catalyst. An unsaturated lactone could also be prepared following the same strategy and preliminary esterification of methyl ricinoleate.

The scope of this reaction was further extended by implementation of tandem $\mathrm{RCM} /$ hydrogenation or domino $\mathrm{RCM} / \mathrm{CM}$ transformations (Scheme 20). As depicted in Scheme 20b, the tetrahydropyran derivative 41 was obtained in good yield via RCM reaction in a single reaction, in the presence or methyl acrylate or acrylonitrile, which concomitantly delivered the bifunctional co-products, suitable as monomer precursors, upon cascade cross-metathesis without hampering the efficiency of the RCM reaction.

In a continuous effort toward the implementation of environmentally friendly processes, the potential of Thermo Morphic Solvent systems (TMS) [91] in olefin metathesis was explored with an emphasis on FAME and methyl undecenoate arising from castor oil [92].

It was demonstrated that a TMS system comprising of Propylene Carbonate (PC) as the polar solvent, Ethyl Acetate (EA) as the medium polarity solvent and CycloHexane (CH) as the apolar phase was suitable for the synthesis of a polyester precursor (Scheme 21). Interestingly, a simple phase separation and extraction of the polar phase with $\mathrm{CH}$ furnished the desired product with a ruthenium content 

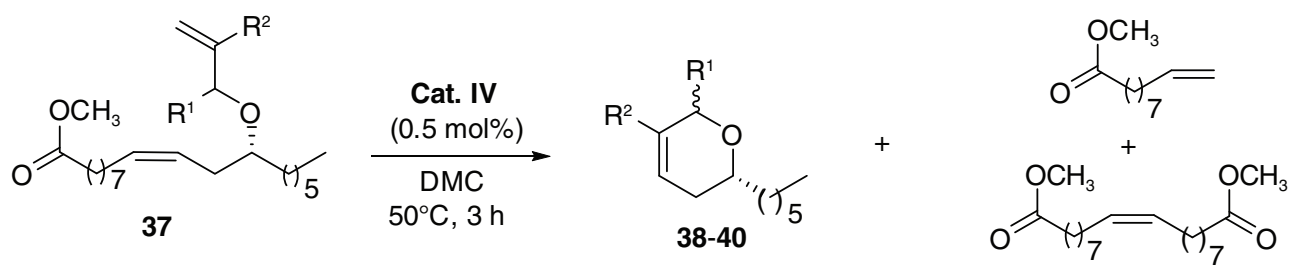

$$
\begin{aligned}
& \mathrm{R}^{1}=\mathrm{CH}_{3}, \mathrm{R}^{2}=\mathrm{H} \\
& \mathrm{R}^{1}=\mathrm{H}, \mathrm{R}^{2}=\mathrm{CH}_{3}, \mathrm{Y} \\
& \mathrm{R}^{1}=\mathrm{Ph}, \mathrm{R}^{2}=\mathrm{H},
\end{aligned}
$$

Conv. $=100 \% 38, Y=99 \%$ *

Conv. $=100 \% 39, \mathrm{Y}=98 \%$

Conv. $=95 \% 40, Y=90 \%{ }^{*}$

*Mixture of diastereoisomers

Scheme 19

Methyl ricinoleate-based dihydropyrans catalytic synthesis.<smiles>C=CCOC(CC)C/C=C/[IH+]C(=O)OC</smiles>

22

a)

22

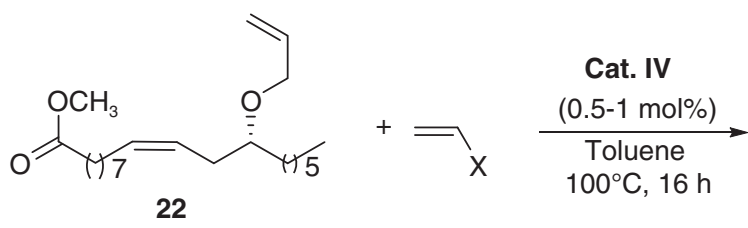

$\underset{\text { 1) Cat. IV - catalyzed RCM }}{\stackrel{\mathrm{H}_{2}(10 \text { bar }), 75^{\circ} \mathrm{C}, 14 \mathrm{~h}}{\longrightarrow}}$$$
\text { 2) } \mathrm{H}_{2}(10 \mathrm{bar}), 75^{\circ} \mathrm{C}, 14 \mathrm{~h}
$$

b)

\section{Scheme 20}

Tandem and domino transformation of methyl ricinoleate derivatives.<smiles>COC(=O)[18O][14C](=O)C(=O)OC</smiles>

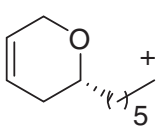

$4192-93 \%$<smiles>[X]C=CNC(=O)OC</smiles>

$\mathrm{X}=\mathrm{CO}_{2} \mathrm{CH}_{3}, 91 \%$ $\mathrm{X}=\mathrm{CN}, 65 \%$ of $62 \mathrm{ppm}$ (Th $\sim 2500 \mathrm{ppm})$. A rapid filtration on a short plug of silica was sufficient to decrease the ruthenium content below 1 ppm. Further studies demonstrated that ethyl acetate could be replaced by methyl undecenoate resulting in a more efficient reaction.

\section{TERPENE AND EUGENOL DERIVATIVES}

\subsection{Cross-Metathesis with Terpene Derivatives}

Olefin metathesis was then applied to other types of unsaturated natural products including monoterpenes, and eugenol substrates derived from essential oils from cloves, cinnamon, etc. or lignin degradation. Most terpenes contain at least one carbon-carbon double bond either included in a cyclic structure or in a linear isoprenoid structure, which is prone to give olefin metathesis transformation. However, due to the presence of other double bonds or oxygenated functional groups (alcohol or aldehyde), metathesis with these substrates has not been studied extensively [93-95]. There are more examples for which terpene derivatives have been modified on purpose by introduction of an olefinic or alkynyl group prior to a metathesis step. However, direct cross-metathesis from natural terpenes represents a straightforward route to produce new functionalized derivatives, and provides more direct and greener strategies to synthesize known products previously prepared using multistep procedures.

We have investigated the cross-metathesis reaction of citronellal, citronellol and citral with methyl acrylate and methacrylate (Scheme 22) [18]. It is noteworthy that if the cross-metathesis with acrylate destroys the C10 isoprenoid structure of the initial terpenes, cross-metathesis with methacrylate gives birth to new products that belong to the terpene family. 


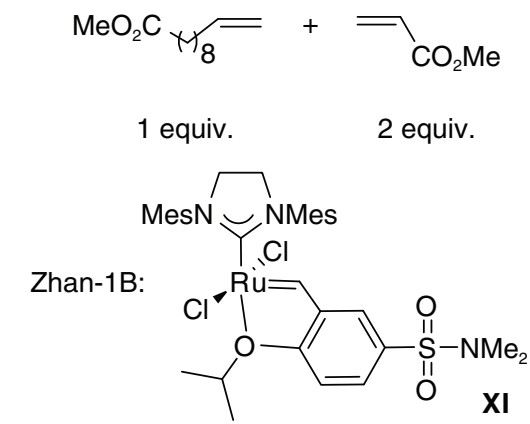

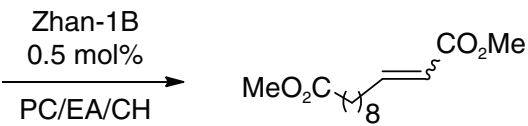

$80^{\circ} \mathrm{C}, 3 \mathrm{~h}$

Conv. $88 \%$
PC: Propylene Carbonate

EA: Ethyl Acetate

$\mathrm{CH}$ : CycloHexane

Scheme 21

Cross-metathesis of methyl undecenoate with methyl acrylate in a TMS system.

From our previous experience in cross-metathesis involving electron-deficient olefins, we selected a second generation phosphine-free ruthenium catalyst, namely the Hoveyda type catalyst IV.

Starting from the monoolefins citronellal and citronellol, and methyl acrylate as metathesis partner, the best conditions were obtained with 2 equivalents of acrylate in dimethyl carbonate as solvent with $2 \mathrm{~mol} \%$ of the Hoveyda second generation catalyst $\mathbf{I V}$ at $60^{\circ} \mathrm{C}$ for $15 \mathrm{~h}$. Under these conditions, complete conversion of the terpene was observed and the products were isolated in $68 \%$ yield (Scheme 22). GC and ${ }^{1} \mathrm{H}$ NMR analyses revealed that the sole $E$-stereoisomer was formed. In the case of the commercially available citral, which is a mixture of $(Z)$ - and $(E)$ isomers (neral and geranial), full conversion also took place at $80^{\circ} \mathrm{C}$ in toluene or dimethyl carbonate, but the reaction was not selective and only $44 \%$ isolated yield of the desired product was obtained.

It turned out that the conditions used for cross-metathesis with methyl acrylate were not suitable for cross-metathesis with methyl methacrylate as full conversion could not be obtained even at $100^{\circ} \mathrm{C}$ in toluene or dimethyl carbonate. The best results were obtained when the reactions were carried out in an excess of methyl methacrylate (29 equivalents with respect to the terpene) without additional solvent in the presence of $2 \mathrm{~mol} \%$ of catalyst IV at $90^{\circ} \mathrm{C}$ during $8 \mathrm{~h}$. Selective and complete cross-metathesis reactions were observed with citronellal and citronellol in these conditions. Side polymerization of the excess of methyl methacrylate required an additional precipitation step and the desired products were isolated in $70-75 \%$ yields (Scheme 22). In accordance with the results obtained from citral with acrylate, the cross-metathesis of this dienic substrate proved to be less selective and the corresponding terpenoid was isolated in only $40 \%$ yield after reaction under neat conditions.
The products arising from cross-metathesis with methyl methacrylate also presented a $E$-configuration as shown by NOE NMR experiments.

This study on cross-metathesis of terpenes with acrylates highlights that the trisubstituted isoprenoid double bond is reactive with this type of electron deficient olefins and that the reaction is $E$-stereoselective. This is not the case with acrylonitrile, which is reluctant for this type of crossmetathesis with terpenes. This strategy is much more direct and atom economic than previous multistep procedures that have been proposed to synthesize the products resulting from citronellol/methyl acrylate [96] citronellol/methyl methacrylate [97, 98] and citral/methyl methacrylate $[99,100]$ cross-metathesis.

\subsection{Cross-Metathesis of Electron Deficient Olefins with Eugenol Derivatives}

We then turned our attention to natural products featuring an allylbenzene motif. These are typically eugenol derivatives present in some essential oils or arising from hydrolytic or thermal degradation of lignocellulosic biomass. We first investigated the cross-metathesis of eugenol with methyl acrylate and then extended the study to other electron deficient olefins such as methyl methacrylate, acrylonitrile and amides.

The metathesis of eugenol with 2 equivalents of acrylate in the presence of the second generation Hoveyda catalyst IV ( $2 \mathrm{~mol} \%$ ) in dimethyl carbonate at $80^{\circ} \mathrm{C}$ led to complete conversion of eugenol within $3 \mathrm{~h}$. However the reaction was not selective and led to 3 major products: one resulting from the expected cross-metathesis, one arising from tandem metathesis/double bond migration featuring the same number of carbon atoms, and a shorter third one resulting from tandem double bond migration/metathesis (Scheme 23) [101]. 


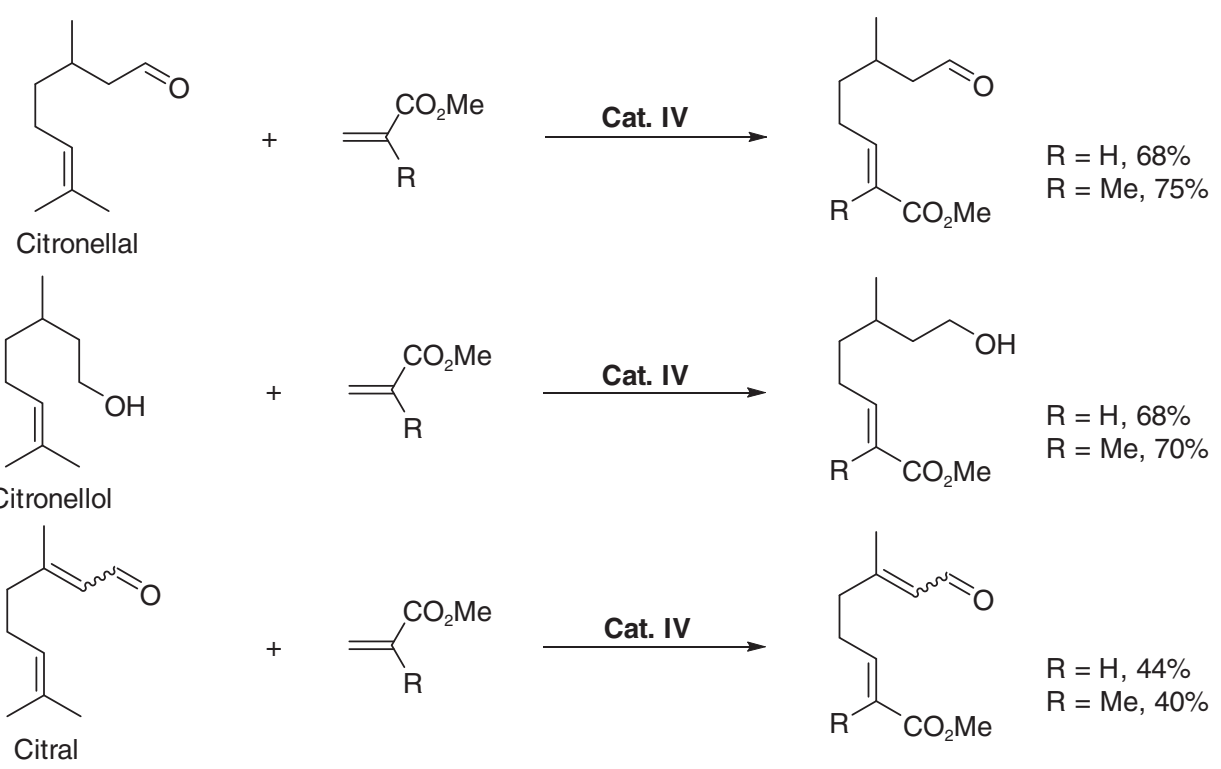

Scheme 22

Cross metathesis of 3 monoterpenoids with methyl acrylate and methacrylate.

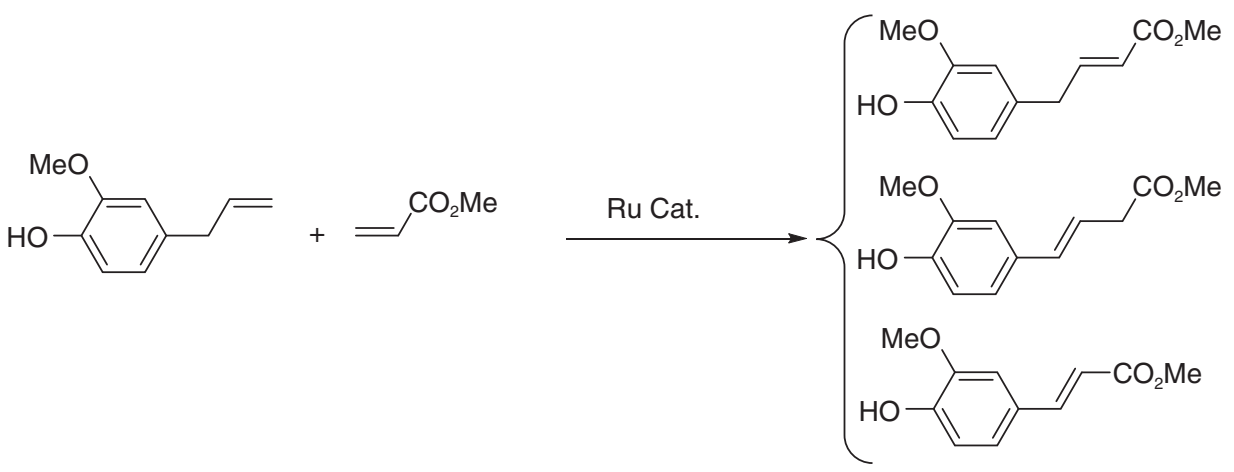

Scheme 23

Cross-metathesis of eugenol with methyl acrylate.

The possibility of isomerization via carbon-carbon double bond migration is well known in olefin metathesis with second generation ruthenium catalysts. This type of reaction is favoured in the present case because the resulting styrene products present a double bond conjugated with the phenyl ring. In order to avoid this side reaction, the use of a hydride scavenger inhibiting the formation of metal hydride species responsible for catalytic isomerization is recommended. 1,4-Benzoquinone has been extensively used to prevent this reaction, which often takes place in the presence of olefin metathesis ruthenium catalysts. Using $5 \mathrm{~mol} \%$ of benzoquinone under the previous reaction conditions, the formation of the expected methyl (4-hydroxy-3-methoxyphenyl)-4-but-2-enoate became selective with a ratio of this product to its isomerized isomer of $91: 9$ leading to $78 \%$ isolated yield.

For each electron-deficient olefin, experimental conditions were found allowing full conversion of the eugenol derivative and isolation of satisfactory yields of the major products (Scheme 24) [101].

They can be summarized as follows:

- for methyl acrylate: $2 \mathrm{~mol} \%$ of Hoveyda catalyst IV in dimethyl carbonate at $80^{\circ} \mathrm{C}$ with $5 \mathrm{~mol} \%$ of 1,4-benzoquinone;

- for methyl methacrylate: $2 \mathrm{~mol} \%$ of Hoveyda catalyst IV without solvent (30 equivalents of methacrylate) at $90^{\circ} \mathrm{C}$ with $5 \mathrm{~mol} \%$ of 1 ,4-benzoquinone; 
<smiles>COc1cc(CC=CC(C)=O)ccc1O</smiles>

$78 \%$<smiles>COc1cc(CC=C(C)C(C)=O)ccc1O</smiles>

$60 \%$

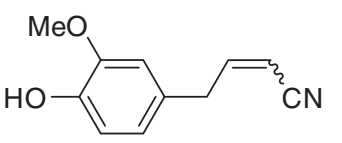

$82 \%$

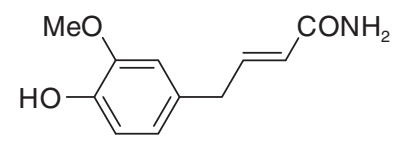

$60 \%$

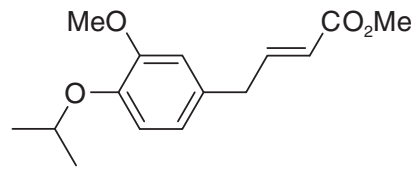

$85 \%$

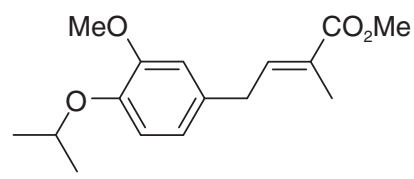

$78 \%$

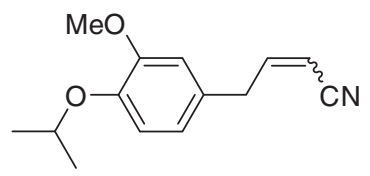

$80 \%$

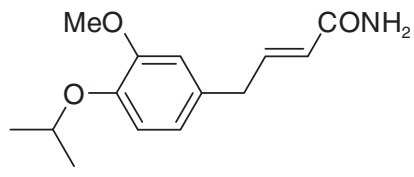

$57 \%$

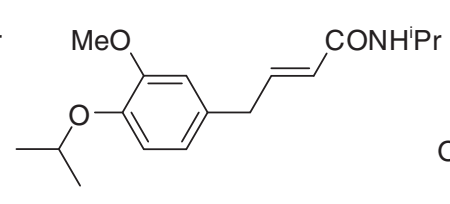

$53 \%$<smiles>COC(C)=CCCc1ccc(OC(C)=O)c(OC)c1</smiles>

$81 \%$<smiles>COc1cc(CC=C(C)C(C)=O)ccc1OC(C)=O</smiles>

$72 \%$<smiles>COc1cc(C/C=C\C#N)ccc1OC(C)=O</smiles>

$79 \%$<smiles>CCCNC(=O)/C=C/Cc1ccc(O)c(OC)c1</smiles>

$70 \%$

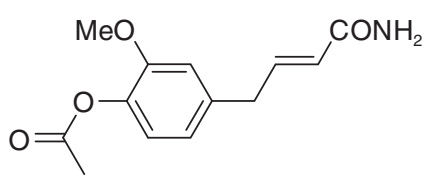

$65 \%$

Scheme 24

Eugenol products arising from cross-metathesis with various electron-deficient olefins.

- for acrylonitrile: $2 \mathrm{~mol} \%$ of Hoveyda catalyst IV in diethyl carbonate at $100^{\circ} \mathrm{C}$ with slow addition of the catalyst in the presence of $5 \mathrm{~mol} \%$ of 1,4-benzoquinone;

- for amides: $2 \mathrm{~mol} \%$ of Hoveyda catalyst IV in dimethyl carbonate at $80^{\circ} \mathrm{C}$ with slow addition of the catalyst in the presence of $5 \mathrm{~mol} \%$ of 1,4-benzoquinone.

The new disubstituted olefins resulting from these crossmetathesis reactions exhibited the expected stereochemistry. They were all $E$-isomers except the nitrile derivatives, which contained both $Z$ - and $E$-isomers with a $Z / E$ ratio of 2:1.

\section{SEQUENTIAL METATHESIS/ELIMINATION REACTION: STRAIGHTFORWARD ACCESS TO CONJUGATED DIENES}

Following our works on cross-metathesis from natural products, we explored the possibility of associating two
$\mathrm{RC}$ transformations in a sequential manner to produce conjugated bio-sourced dienes. Indeed, we have recently shown that $\left[\mathrm{Cp} * \mathrm{Ru}(\mathrm{MeCN})_{3}\right]\left[\mathrm{PF}_{6}\right]$ catalyzed elimination reactions from allylic carbonates to generate dienes via an allylic activation/elimination mechanism [102]. Thus we applied a 2 step strategy involving first cross-metathesis with allylic chloride followed by $\mathrm{HCl}$ elimination as shown in Scheme 25.

The cross-metathesis step was achieved using 6 equivalents of allylic chloride in refluxing dichloromethane in the presence of $2 \mathrm{~mol} \%$ of the Umicore M51 catalyst VIII [103]. Under these conditions, no isomerization of fatty aliphatic chain and only trace amounts of self-metathesis of the natural substrate were observed. Five natural products and two allylic chlorides were used to exemplify the generality of the transformation. 1-Decene, methyl 10-undecenoate and 10-undecenenitrile as fatty acid derivatives, citronellal as a terpene and eugenyl acetate were cross-metathesized 


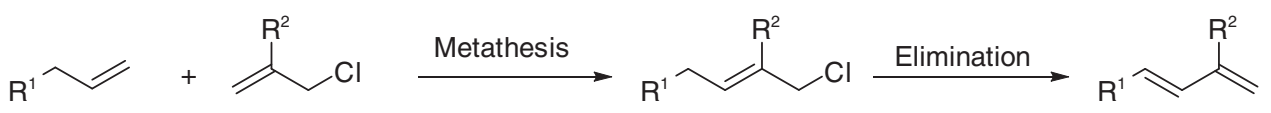

Scheme 25

Sequential procedure to produce 1,3-dienes.

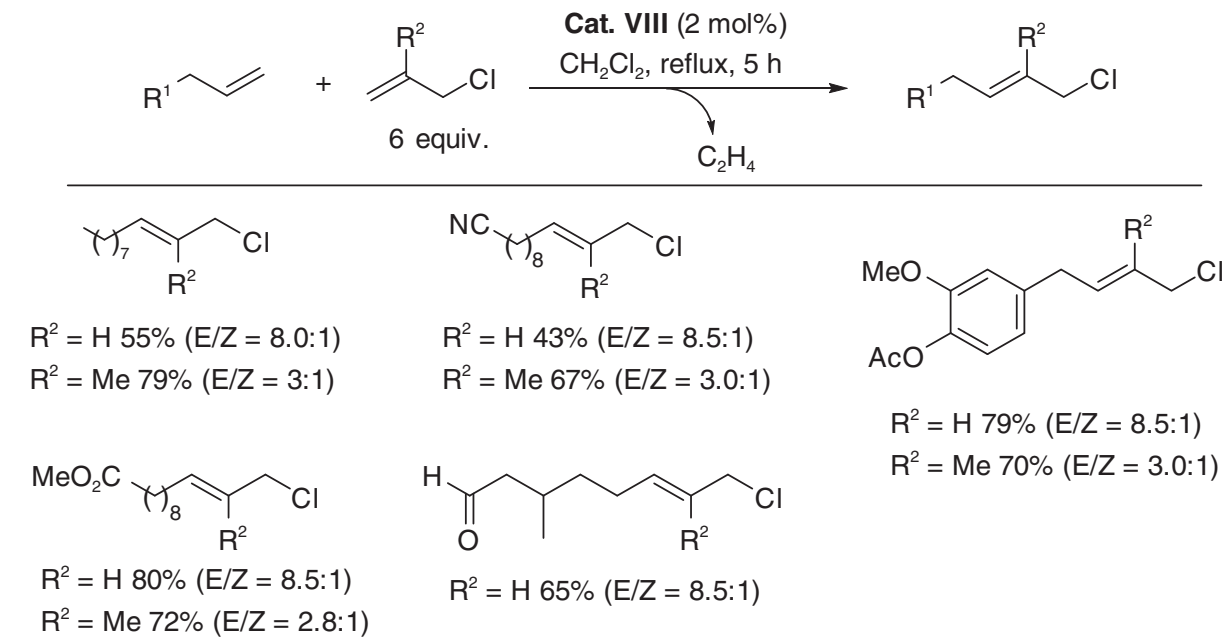

Scheme 26

Allylic products from cross-metathesis of allylic chlorides with natural products.

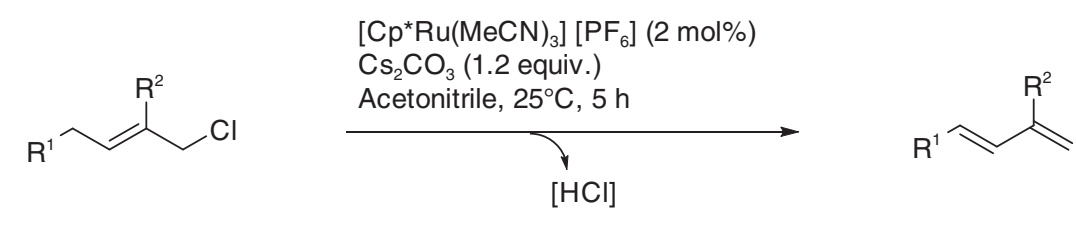

$\mathrm{R}^{2}=\mathrm{H} 75 \%(\mathrm{E} / \mathrm{Z}=8: 1)$
$\mathrm{R}^{2}=\mathrm{Me} 72 \%$

Scheme 27

Formation of terminal dienes from allylic chlorides. 
with allyl and 2-methylprop-2-enyl chlorides. The corresponding internal olefins were isolated in good yields as mixtures of $Z$ - and $E$-isomers with the $E$-isomer as the major product (Scheme 26).

The elimination reaction was then studied in details from methyl 12-chlorododec-10-enoate and we showed that the reaction could be performed at room temperature in acetonitrile in the presence of $5 \mathrm{~mol} \%$ of $\left[\mathrm{Cp} * \mathrm{Ru}(\mathrm{MeCN})_{3}\right]\left[\mathrm{PF}_{6}\right]$ as catalyst and 1.2 equivalent of $\mathrm{Cs}_{2} \mathrm{CO}_{3}$ as a base. The terminal dienes were isolated in good yields (Scheme 27). For the dienes resulting from elimination from unsubstituted allylic chlorides, the internal double bond exhibited both $E$ and $Z$-configuration with $E / Z$ ratio of 8 to 1, except in the case of the eugenol derivative where the internal double bond conjugated with the phenyl ring presented only the $E$-configuration. For the other dienes obtained from 2-methylprop-2-enyl chloride in the first metathesis step, only the $E$-isomers were obtained in a highly stereoselective manner [103].

This catalytic sequence requires the elimination of the solvent of the metathesis step which is not suitable for the elimination reaction, where the presence of the coordinating acetonitrile is required.

However, this protocol appears to be quite general as far as the substrate contains a removable hydrogen atom at the $\alpha$-carbon of the initial olefin, and it can be applied as a green solution liberating only $\mathrm{HCl}$ trapped by the carbonate base as by product to produce conjugated terminal dienes.

\section{CONCLUSION}

The above results show that several commercially available alkylidene-ruthenium catalysts allow selective, efficient transformations of unsaturated renewables, arising from plant oils, via cross-metathesis with electron deficient olefins: acrylates, methacrylates, acrylonitrile, acrylamides. They provide access directly to bifunctional linear products without $\mathrm{C}=\mathrm{C}$ bond isomerization, especially they allow the access to a variety of nitrile esters via cross-metathesis with acrylonitrile and, after hydrogenation with the ruthenium catalyst, to linear amino acid derivatives, useful as polymer precursors. The introduction of catalyst solution via syringe pump allows to reach high TON. Several routes from alkenes to functional conjugated dienes have been established via enyne metathesis of renewable alkenes with alkyne, and via cross-metathesis with simple allylic chlorides followed by ruthenium-catalyzed dehydrohalogenation. Olefin metathesis opens new opportunities allowing access to cyclic molecules with olfactory properties from natural products and giving value to natural terpenes and eugenol via cross-metathesis without isomerization.

There is no doubt that further investigation in cascade, tandem and sequential catalytic transformations of renewables involving at least one metathesis step will provide chemical industry with new atom economic and sustainable processes.

\section{ACKNOWLEDGMENTS}

The authors thank IFP Energies nouvelles, Arkema company, the European Union Seventh Framework Program (FP7/2007-2013) under grant agreement No. 241718 EuroBioRef, ADEME, The Region Bretagne, the bilateral France-Tunisia PHC-UTIQUE No. 09G1203, CNRS, the French Ministry of Research, the University of Rennes 1, for support. Thanks also go to Umicore Precious Metals Chemistry, Hanau (Germany) for loan of metathesis catalysts.The authors wish to acknowledge all the students and researchers from academy and industry, whose names appear in the Rennes Catalysis team references for their contribution to the development of this topic.

\section{REFERENCES}

1 Biermann U., Bornscheuer U., Meier M.A.R., Metzger J.O., Schäfer H.J. (2011) Oils and fats as renewable raw materials in chemistry, Angewandte Chemie International Edition 50, 3854-3871.

2 Hill K. (2000) Fats and oils as oleochemical raw materials, Pure \& Applied Chemistry 72, 1255-1264.

3 Winkler M., Meier M.A.R. (2014) Olefin cross-metathesis as a valuable tool for the preparation of renewable polyesters and polyamides from unsaturated fatty acid esters and carbamates, Green Chemistry 16, 3335-3340.

4 Chikkali S., Mecking S. (2012) Refining of plant oils to chemicals by olefin metathesis, Angewandte Chemie International Edition 51, 5802-5808.

5 Corma A., Iborra S., Velty A. (2007) Chemical routes for the transformation of biomass into chemicals, Chemical Reviews 107, 2411-2502.

6 Deuss P.J., Barta K., de Vries J.G. (2014) Homogeneous catalysis for the conversion of biomass and biomass-derived platform chemicals, Catalysis Science \& Technology 4, 1174-1196.

7 Montero de Espinosa L., Meier M.A.R. (2012) Olefin metathesis of renewable platform chemicals, Topics in Organometallic Chemistry 39, 1-44.

8 Marshall A.-L., Alaimo P.J. (2010) Useful products from complex starting materials: common chemicals from biomass feedstocks, Chemistry: An European Journal 16, 4970-4980.

9 Vennestrøm P.N.R., Osmundsen C.M., Christensen C.H., Taarning E. (2011) Beyond petrochemicals: The renewable chemicals industry, Angewandte Chemie International Edition 50, 10502-10509.

10 Gallezot P. (2012) Conversion of biomass to selected chemical products, Chemical Society Reviews 41, 1538-1558.

11 Connon S.J., Blechert S. (2003) Recent developments in olefin cross-metathesis, Angewandte Chemie International Edition 42, 1900-1923. 
12 Mol J.C. (2004) Catalytic metathesis of unsaturated fatty acid esters and oils, Topics in Catalysis 27, 97-104.

13 Mol J.C. (2002) Application of olefin metathesis in oleochemistry: an example of green chemistry, green chemistry 4, 5-13.

14 Bruneau C., Fischmeister C., Miao X., Malacea R., Dixneuf P.H. (2010) Cross-metathesis with acrylonitrile and applications to fatty acid derivatives, European Journal of Lipid Science and Technology 112, 3-9.

15 Miao X., Dixneuf P.H., Fischmeister C., Bruneau C. (2011) A green route to nitrogen-containing groups: the acrylonitrile cross-metathesis and applications to plant oils derivatives, Green Chemistry 13, 2258-2271.

16 Rybak A., Meier M.A.R. (2007) Cross-metathesis of fatty acid derivatives with methyl acrylate: renewable raw materials for the chemical industry, Green Chemistry 9, 1356-1361.

17 Rybak A., Meier M.A.R. (2008) Cross-metathesis of oleyl alcohol with methyl acrylate: optimization of reaction conditions and comparison of their environmental impact, Green Chemistry 10, 1099-1104.

18 Bilel H., Hamdi N., Zagrouba F., Fischmeister C., Bruneau C. (2011) Cross-metathesis transformations of terpenoids in dialkyl carbonate solvents, Green Chemistry 13, 1448-1452.

19 Yadav G.D., Doshi N.S. (2002) Development of a green process for poly-a-olefin based lubricants, Green Chemistry 4 , $528-540$

20 Warwel S., Tillack J., Demes C., Kunz M. (2001) Polyesters of $\omega$-Unsaturated Fatty Acid Derivatives, Macromolecular Chemistry and Physics 202, 1114-1121.

21 van Dam P.B., Mittlmeijer M.C., Boelhouwer C. (1972) Metathesis of unsaturated fatty acid esters by a homogeneous tungsten hexachloride-tetramethyltin catalyst, Journal of the Chemical Society, Chemical Communications 1221-1222.

22 Verkuijlen E., Kapteijn F., Mol J.C., Boelhouwer C. (1977) Heterogeneous metathesis of unsaturated fatty acid esters, Journal of the Chemical Society, Chemical Communications 198-199.

23 Bosma R.H.A., van Aardweg F., Mol J.C. (1981) Cometathesis of methyl oleate and ethylene; a direct route to methyl dec-9-enoate, Journal of the Chemical Society, Chemical Communications 1132-1133.

24 Newman T.H., Rand C.L., Burdett K.A., Maughon B.R., Morrison D.L., Wasserman E.P., WO02/076920.

25 Grubbs R.H., Nguyen S.-B.T, Johnson L.K., Hillmyer M.A., Fu G.C., WO96/04289.

26 Thurier C., Olivier-Bourbigou H., Dixneuf P.H., Hillion G., EP1698686, US 2006/0079704.

27 Burdett K.A., Harris L.D., Margl P., Maughon B.R., Mokhtar-Zadeh T., Saucier P.C., Wasserman E.P. (2004) Renewable Monomer Feedstocks via Olefin Metathesis: Fundamental Mechanistic Studies of Methyl Oleate Ethenolysis with the First-Generation Grubbs Catalyst, Organometallics 23, 2027-2047.

28 Chauvin Y., Gilbert B., Guibard I. (1990) Catalytic dimerization of alkenes by nickel complexes in organochloroaluminate molten salts, Journal of the Chemical Society, Chemical Communications 1715-1716.

29 Olivier-Bourbigou H., Magna L. (2002) Ionic liquids: perspectives for organic and catalytic reactions, Journal of Molecular Catalysis A: Chemical 182, 419-437.
30 Zhao D., Wu M., Kou Y., Min E. (2002) Ionic liquids: applications in catalysis, Catalysis Today 74, 157-189.

31 Welton T. (2004) Ionic liquids in catalysis, Coordination Chemistry Reviews 248, 2459-2477.

32 Pârvulescu V.I., Hardacre C. (2007) Catalysis in Ionic Liquids, Chemistry Reviews 107, 2615-2665.

33 Chauvin Y., Olivier-Bourbigou H. (1995) Nonaqueous ionic liquids as reaction solvents, Chemtech 25, 26.

34 Gürtler C., Jautelat M., EP1035093A2.

35 Buijsman R.C., van Vuuren E., Sterrenburg J.G. (2001) Ruthenium-Catalyzed Olefin Metathesis in Ionic Liquids, Organic Letters 3, 3785-3787.

36 Mayo K.G., Nearhoof E.H., Kiddle J.J. (2002) MicrowaveAccelerated Ruthenium-Catalyzed Olefin Metathesis, Organic Letters 4, 1567-1570.

37 Ding X., Lv X., Hui B., Chen Z., Xiao M., Guo B., Tang W. (2006) Olefin self-cross-metathesis catalyzed by the secondgeneration Grubbs carbene complex in room temperature ionic liquids, Tetrahedron Letters 47, 2921-2924.

38 Williams D.B.G., Ajam M., Ranwell A. (2006) Highly Selective Metathesis of 1-Octene in Ionic Liquids, Organometallics 25, 3088-3090.

39 Sémeril D., Olivier-Bourbigou H., Bruneau C., Dixneuf P.H. (2002) Alkene metathesis catalysis in ionic liquids with ruthenium allenylidene salts, Chemical Communications 146-147.

40 Csihony S., Fischmeister C., Bruneau C., Horvath I.T., Dixneuf P.H. (2002) First ring-opening metathesis polymerization in an ionic liquid, Efficient recycling of a catalyst generated from a cationic ruthenium allenylidene complex, New Journal of Chemistry 26, 1667-1670.

41 Thurier C., Fischmeister C., Bruneau C., Olivier-Bourbigou H., Dixneuf P.H. (2007) Ionic imidazolium containing ruthenium complexes and olefin metathesis in ionic liquids, Journal of Molecular Catalysis A: Chemistry 268, 127-133.

42 Thurier C., Fischmeister C., Bruneau C., Olivier-Bourbigou H., Dixneuf P.H. (2008) Ethenolysis of Methyl Oleate in RoomTemperature Ionic Liquids, ChemSusChem 1, 118-122.

43 Ackermann L., Bruneau C., Dixneuf P.H. (2001) Simple new three-component catalytic system for enyne metathesis, Synlett 397-399.

44 Sémeril D., Bruneau C., Dixneuf P.H. (2002) Imidazolium and Imidazolinium Salts as Carbene Precursors or Solvent for Ruthenium-Catalysed Diene and Enyne Metathesis, Advanced Synthesis \& Catalysis 344, 585-595.

45 Crowe W.E., Goldberg D.R. (1995) Acrylonitrile CrossMetathesis: Coaxing Olefin Metathesis Reactivity from a Reluctant Substrate, Journal of the American Chemical Society 117, 5162-5163.

46 Gessler S., Randl S., Blechert S. (2000) Synthesis and metathesis reactions of a phosphine-free dihydroimidazole carbene ruthenium complex, Tetrahedron Letters 41, 9973-9976.

47 Love J.A., Morgan J.P., Trnka T.M., Grubbs R.H. (2002) A Practical and Highly Active Ruthenium-Based Catalyst that Effects the Cross-metathesis of Acrylonitrile, Angewandte Chemie International Edition 41, 4035-4037.

48 Hoveyda H., Vezina M. (2005) Synthesis of Unsaturated Amino Alcohols through Unexpectedly Selective RuCatalyzed Cross-Metathesis Reactions, Organic Letters 7, 2113-2116. 
49 Bieniek M., Bujok R., Cabaj M., Lugan N., Lavigne G., Arlt D., Grela K. (2006) Advanced Fine-Tuning of Grubbs/Hoveyda Olefin Metathesis Catalysts: A Further Step toward an Optimum Balance between Antinomic Properties, Journal of the American Chemical Society 128, 13562-13564.

50 Michaut A., Boddaert T., Coquerel Y., Rodriguez J. (2007) Reluctant cross-metathesis reactions: The highly beneficial effect of microwave irradiation, Synlett 2867-2871.

51 Rivard M., Blechert S. (2003) Effective and Inexpensive Acrylonitrile Cross-Metathesis: Utilisation of Grubbs II Precatalyst in the Presence of Copper(I) Chloride, European Journal of Organic Chemistry 2225-2228.

52 Malacea R., Fischmeister C., Bruneau C., Dubois J.-L., Couturier J.-L., Dixneuf P.H. (2009) Renewable materials as precursors of linear nitrile-acid derivatives via crossmetathesis of fatty esters and acids with acrylonitrile and fumaronitrile, Green Chemistry 11, 152-155.

53 Miao X., Malacea R., Fischmeister C., Bruneau C., Dixneuf P.H. (2011) Ruthenium-alkylidene catalysed cross-metathesis of fatty acid derivatives with acrylonitrile and methyl acrylate: a key step toward long-chain bifunctional and amino acid compounds, Green Chemistry 13, 2911-2919.

54 Fabritius D., Schäfer H.J., Steinbüchel A. (1998) Bioconversion of sunflower oil, rapeseed oil and ricinoleic acid by Candida tropicalis M25, Applied Microbiology and Biotechnology 50, 573-578.

55 Dinger M.B., Mol J.C. (2002) High Turnover Numbers with Ruthenium-Based Metathesis Catalysts, Advanced Synthesis \& Catalysis 344, 671-677.

56 Ngo H.L., Jones K., Foglia T.A. (2006) Journal of the American Oil Chemists' Society 83, 629-634.

57 Marvey B.B., Segakweng C.K., Vosloo M.H.C. (2008) Ruthenium Carbene Mediated Metathesis of Oleate-Type Fatty Compounds, International Journal of Molecular Sciences 9, 615-625.

58 Takemoto S., Kawamura H., Yamada Y., Okada T., Ono A., Yoshikawa E., Mizobe Y., Hidai M. (2002) Ruthenium Complexes Containing Bis(diarylamido)/Thioether Ligands: Synthesis and their Catalysis for the Hydrogenation of Benzonitrile, Organometallics 21, 3897-3904.

59 Li T., Bergner I., Haque F.N., Iuliis M.Z.-D., Song D., Morris R.H. (2007) Hydrogenation of Benzonitrile to Benzylamine Catalyzed by Ruthenium Hydride Complexes with $\mathrm{P}-\mathrm{NH}-\mathrm{NH}-\mathrm{P}$ Tetradentate Ligands: Evidence for a Hydridic-Protonic Outer Sphere Mechanism, Organometallics 26, 5940-5949.

60 Das S., Zhou S., Addis D., Enthaler S., Junge K., Beller M. (2010) Selective catalytic reductions of amides and nitriles to amines, Topics in Catalysis 53, 979-984.

61 Enthaler S., Junge K., Addis D., Erre G., Beller M. (2008) A practical and benign synthesis of primary amines through ruthenium-catalyzed reduction of nitriles, ChemSusChem 1, 1006-1010.

62 Enthaler S., Addis D., Junge K., Erre G., Beller M. (2008) A practical and benign synthesis of primary amines through ruthenium-catalyzed reduction of nitriles, Chemistry: an, European Journal 14, 9491-9494.

63 Addis D., Enthaler S., Junge K., Wendt B., Beller M. (2009) Ruthenium N-heterocyclic carbene catalysts for selective reduction of nitriles to primary amines, Tetrahedron Letters 50, 3654-3656.
64 Miao X., Fischmeister C., Dixneuf P.H., Bruneau C., Dubois J.-L., Couturier J.-L. (2012) Tandem Catalytic Acrylonitrile Cross-Metathesis and Hydrogenation of Nitriles with Ruthenium Catalysts: Direct Access to Linear $\alpha, \omega$-Aminoesters from Renewables, ChemSusChem 5, 1410-1414.

65 Couturier J.-L., Dubois J.-L., Miao X., Fischmeister C., Bruneau C., Dixneuf P.H. (2011) Brevet: FR 2959742A120111111; PCT Int. Appl., WO 2011138051A1 20111110.

66 Bielawski C.W., Louie J., Grubbs R.H. (2000) Tandem Catalysis: Three Mechanistically Distinct Reactions from a Single Ruthenium Complex, Journal of the American Chemical Society 122, 12872-12873.

67 Watson M.D., Wagener K.B. (2000) Tandem Homogeneous Metathesis/Heterogeneous Hydrogenation: Preparing Model Ethylene/CO2 and Ethylene/CO Copolymers, Macromolecules 33, 3196-3201.

68 Drouin S.D., Zamanian F., Fogg D.E. (2001) Multiple Tandem Catalysis: Facile Cycling between Hydrogenation and Metathesis Chemistry, Organometallics 20, 5495-5497.

69 Miao X., Bidange J., Dixneuf P.H., Fischmeister C., Bruneau C., Dubois J.-L., Couturier J.-L. (2012) Ruthenium-benzylidenes and -indenylidenes as efficient catalysts for the hydrogenation of aliphatic nitriles into primary amines, ChemCatChem 4, 1911-1916.

70 Ho T.T.T., Jacobs T., Meier M.A.R. (2009) A Designof-Experiments Approach for the Optimization and Understanding of the Cross-Metathesis Reaction of Methyl Ricinoleate with Methyl Acrylate, ChemSusChem 2, 749-754.

71 Behr A., Perez Gomes J., Bayrak Z. (2011) Cross-metathesis of methyl 10-undecenoate with diethyl maleate: Formation of an $\alpha, \varpi$-diester via a metathesis reaction network, European Journal of Lipid Science and Technology 113, 189-196.

72 Djigoué G.B., Meier M.A.R. (2009) Improving the selectivity for the synthesis of two renewable platform chemicals via olefin metathesis, Applied Catalysis A 368, 158-162.

73 Dubois J.-L., Gillet J.-P. (2008) Procédé de co-production de carbonates cycliques et de nitriles et/ou d'amines gras, Patent WO2008145941A9.

74 Chauvel A., Lefebvre G. (1989) Petrochemical Processes, Editions Technip 2, 274.

75 Miao X., Fischmeister C., Dixneuf P.H., Bruneau C., Dubois J.-L., Couturier J.-L. (2012) Polyamide precursors from renewable 10-undecenenitrile and methyl acrylate via olefin cross-metathesis, Green Chemistry 14, 2179-2183.

76 Das G., Trivedi R.K., Vasishtha A.K. (1989) Heptaldehyde and undecylenic acid from castor oil, Journal of the American Oil Chemists' Society 66, 938-941.

77 van der Steen M., Stevens C.V., Eeckhout Y., De Buyck L., Ghelfi F., Roncaglia F. (2008) Undecylenic acid: A valuable renewable building block on route to Tyromycin A derivatives, European Journal of Lipid Science and Technology 110, $846-852$.

78 van der Steen M., Stevens C.V. (2009) Undecylenic Acid: A Valuable and Physiologically Active Renewable Building Block from Castor Oil, ChemSusChem 8, 692-713.

79 Mutlu H., Meier M.A.R. (2010) Castor oil as a renewable resource for the chemical industry, European Journal of Lipid Science and Technology 112, 10-30. 
80 Miao X., Fischmeister C., Bruneau C., Dixneuf P.H. (2009) A direct route to bifunctional aldehyde derivatives via selfand cross-metathesis of unsaturated aldehydes, ChemSusChem 2, 542-545.

81 Bidange J., Fischmeister C., Bruneau C., Dubois J.-L., Couturier J.-L. (2015) Cross-metathesis of bio-sourced fatty nitriles with acrylonitrile, Monatshefte für Chemie 146, 1107-1113.

82 Fischmeister C., Bruneau C. (2011) Ene-yne crossmetathesis with ruthenium carbene catalysts, Beilstein Journal of Organic Chemistry 7, 156-166.

83 Le Ravalec V., Fischmeister C., Bruneau C. (2009) First transformation of unsaturated fatty esters involving enyne cross-metathesis, Advanced Synthesis and Catalysis 351, $1115-1122$.

84 Miao X., Fischmeister C., Bruneau C., Dixneuf P.H. (2008) Dimethyl Carbonate: An Eco-Friendly Solvent in Ruthenium-Catalyzed Olefin Metathesis Transformations, ChemSusChem 1, 813-816.

85 Le Ravalec V., Dupé A., Fischmeister C., Bruneau C. (2010) Improving sustainability in ene-yne cross-metathesis for transformation of unsaturated fatty esters, ChemSusChem $\mathbf{3}$, 1291-1297.

86 Kotha S., Meshram M., Tiwari A. (2009) Advanced approach to polycyclics by a synergistic combination of enyne metathesis and Diels Alder reaction, Chemical Society Reviews 38, 2065-2092.

87 Dupé A., Le Ravalec V., Fischmeister C., Bruneau C. (2013) Stepwise catalytic transformations of renewable feedstock arising from plant oils, European Journal of Lipid Science and Technology 115, 490-500.

88 Zhang H.-J., Demerseman B., Toupet L., Xi Z., Bruneau C. (2008) Novel $\left[\mathrm{Ru}\left(\mathrm{C}_{5} \mathrm{Me}_{4} \mathrm{R}\right)(2\right.$-quinolinecarboxylato)(allyl)] $\left[\mathrm{PF}_{6}\right]$ Complexes as Efficient Catalysts for Highly Regioselective Nucleophilic Substitution of Aliphatic Allylic Substrates, Advanced Synthesis \& Catalysis 350, 1601-1609.

89 Biermann U., Bornscheuer U., Meier M.A.R., Metzger J.O., Schäfer H.J. (2011) Oils and Fats as Renewable Raw materials in Chemistry, Angewandte Chemie International Edition 50, 3854-3871.

90 Dupé A., Achard M., Fischmeister C., Bruneau C. (2012) Methyl ricinoleate as platform chemical for simultaneous production of fine chemicals and polymer precursors, ChemSusChem 5, 2249-2254.

91 Behr A., Toslu N. (1999) One-and two-phase reaction engineering of the hydrosilylation reaction, Chemie- Ingenieur Technik 71, 490-493.
92 Huang S., Bilel H., Zagrouba F., Hamdi N., Bruneau C., Fischmeister C. (2015) Olefin metathesis transformations in thermomorphic multicomponent solvent system, Catalysis Communications 63, 31-34.

93 Yoshikai K., Hayama T., Nishimura K., Yamada K.I., Tomioka K. (2005) Thiol-catalyzed acyl radical cyclization of alkenals, Journal of Organic Chemistry 70, 681-683.

94 Gutierrez S., Tlenkopatchev M.A. (2011) Metathesis of renewable products: degradation of natural rubber via cross-metathesis with $\beta$-pinene using Ru-alkylidene catalysts, Polymer Bulletin 66, 1029-1038.

95 Borré E., Dinh T.H., Caijo F., Crévisy C., Mauduit M. (2011) Terpenic compounds as renewable sources of raw materials for cross-metathesis, Synthesis 2125-2130.

96 Hanessian S., Dhanoa D.S., Beaulieu P.L. (1987) Synthesis of carbocycles from $\omega$-substituted $\alpha, \beta$-unsaturated esters via radical-induced cyclizations, Canadian Journal of Chemistry 65, 1859-1866.

97 Brown R.T., Mayalarp S.P., Watts J. (1997) Synthesis of methyl secolonitoside, Journal of the Chemical Society, Perkin Transactions 1, 1633-1637.

98 Yamagushi K., Shinohara C., Kojima S., Sodeoka M., Tsuji T. (1999) (2E,6R)-8-Hydroxy-2,6-dimethyl-2-octenoic Acid, a Novel Anti-osteoporotic Monoterpene Isolated from Cistanche salsa, Bioscience Biotechnology, Biochemistry 63, 731-735.

99 Zhang Z., Chen J., Yang Z., Tang Y. (2010) Rapid Biomimetic Total Synthesis of ( \pm )-Rossinone B, Organic Letters 12, 5554-5557.

100 Zhao Y.-J., Loh T.-P. (2008) Practical synthesis of 1,5-dimethyl substituted conjugated polyenes from geranyl acetate, Tetrahedron 64, 4972-4978.

101 Bilel H., Hamdi N., Zagrouba F., Fischmeister C., Bruneau C. (2012) Eugenol as a renewable feedstock for the production of polyfunctional alkenes via olefin cross-metathesis, RSC Advances 2, 9584-9589.

102 Beydoun K., Zhang H.-J., Sundararaju B., Demerseman B., Achard M., Xi Z., Bruneau C. (2009) Efficient rutheniumcatalyzed synthesis of [3]-dendralenes from 1,3-dienic allylic carbonates, Chemical Communications 6580-6582.

103 Bilel H., Hamdi N., Zagrouba Z., Fischmeister C., Bruneau C. (2014) Terminal conjugated dienes via a ruthenium-catalyzed cross-metathesis/elimination sequence: application to renewable resources, Catalysis Science \& Technology 4, 2064-2071.

Manuscript submitted in July 2015

Manuscript accepted in August 2015

Published online in March 2016

Cite this article as: P.H. Dixneuf, C. Bruneau and C. Fischmeister (2016). Alkene Metathesis Catalysis: A Key for Transformations of Unsaturated Plant Oils and Renewable Derivatives, Oil Gas Sci. Technol 71, 19. 